\title{
Frequency of occurrence for units of phonemes, morae, and syllables appearing in a lexical corpus of a Japanese newspaper
}

\author{
KATSUO TAMAOKA \\ Hiroshima University, Hiroshima, Japan \\ and \\ SHOGO MAKIOKA \\ Osaka Women's University, Osaka, Japan
}

\begin{abstract}
On the basis of the lexical corpus created by Amano and Kondo (2000), using the Asahi newspaper, the present study provides frequencies of occurrence for units of Japanese phonemes, morae, and syllables. Among the five vowels, /a/ (23.42\%), /i/ (21.54\%), /u/ (23.47\%), and /o/ (20.63\%) showed similar frequency rates, whereas /e/ (10.94\%) was less frequent. Among the 12 consonants, /k/ (17.24\%), /t/ (15.53\%), and /r/ (13.11\%) were used often, whereas $/ \mathrm{p} /(0.60 \%)$ and $/ \mathrm{b} /(2.43 \%)$ appeared far less frequently. Among the contracted sounds, /s j/ (36.44\%) showed the highest frequency, whereas $/ \mathrm{mj} /(0.27 \%)$ rarely appeared. Among the five long vowels, /aR/ (34.4\%) was used most frequently, whereas /uR/ (12.11\%) was not used so often. The special sound / $/$ appeared very frequently in Japanese. The syllable combination $/ \mathrm{k} /+\mathrm{V}+\mathrm{N} /(19.91 \%)$ appeared most frequently among syllabic combinations with the nasal $/ \mathrm{N} /$. The geminate (or voiceless obstruent) /Q/, when placed before the four consonants /p/, /t/, /k/, and /s/, appeared $98.87 \%$ of the time, but the remaining $1.13 \%$ did not follow the definition. The special sounds $/ \mathrm{R} /, / \mathrm{N} /$, and /Q/ seem to appear very frequently in Japanese, suggesting that they are not special in terms of frequency counts. The present study further calculated frequencies for the 33 newly and officially listed morae/syllables, which are used particularly for describing alphabetic loanwords. In addition, the top 20 bi-mora frequency combinations are reported. Files of frequency indexes may be downloaded from the Psychonomic Society Web archive at http://www.psychonomic.org/archive/.
\end{abstract}

The table of fundamental Japanese sounds, which are described in phonological scripts of two types of kana symbols, hiragana or katakana, consists of 101 basic kana, including the special sound of the nasal /N/ (written in hiragana as $h$ and in katakana as $V$ ). However, in modern spoken and written Japanese, it is not unusual to find some morae that are not described in the traditional kana table. One of the reasons for this drastic change in Japanese sounds has been the recent, massive adoption of alphabetic loanwords, especially from English, resulting in various new sounds in modern Japanese. Taking this new trend into consideration, a list of an additional 33 kana (or morae) was officially issued for these loanwords through a cabinet announcement by the Government of Japan (1991). Since kana is a shallow script, whereby orthographic symbols and phonological units correspond to each other on a regular basis, each single kana (occasionally two kana for contracted sounds) corresponds to the phonological unit of a mora. Thus, by counting kana

The authors express their gratitude to Takayuki Arai and Yasushi Hino for their valuable assistance in reviewing this article. Correspondence concerning this article should be addressed to K. Tamaoka, International Student Center, Hiroshima University, 1-1, 1-chome, Kagamiyama, HigashiHiroshima, 739-8523 Japan (e-mail: ktamaoka@hiroshima-u.ac.jp). units, the present study was able to calculate the overall frequencies of occurrence for Japanese phonological units. Through the use of a lexical corpus (Amano \& Kondo, ${ }^{1} 2000$ ) produced on the basis of the Asahi newspaper, the present study provides type and token frequencies of occurrences (hereafter, if not clearly mentioned, frequency refers to frequency of occurrence or frequency counts) for the units of phonemes, morae, and syllables.

The frequency counts for phoneme, mora, and syllable units are useful for estimating the phonological familiarity of a Japanese word by adding or averaging frequencies involved in the target word. For example, the Japanese writing system includes three scripts: kanji, hiragana, and katakana. Although each word is more likely to be written in one script than in another, it is possible to transcribe the target word into other scripts. By transcribing words into unfamiliar scripts, the orthographic familiarity will be severely reduced. Using this process, Besner and Hildebrandt (1987) found that loanwords normally written in katakana were named more quickly than both nonwords and kanji compound words presented in katakana. However, since the same words in different scripts are still pronounced in the same way, it is quite possible that phonological familiarity (frequency in sounds) could be independent of the orthographic familiarity (frequency in 
print) of the target words. Likewise, Tamaoka and Murata (2001) indicated that CVCVCV-structured nonwords with the same vowel repetitions (e.g., /kohomo/) were processed more slowly and less accurately than those with no repetition (e.g., /kohami/). This tendency is called vowel repetition effects. However, Tamaoka and Murata did not use the phonological frequencies of phonemes and morae as a control condition in their experiments. Previous studies involved with the processing units of Japanese phonology (e.g., Cutler \& Otake, 1994; Otake, Hatano, \& Yoneyama, 1996; Otake, Hatano, Cutler, $\&$ Mehler, 1993; Tamaoka \& Terao, 2004) and with mora timing (e.g., Han, 1992; Sugito, 1989; see Vance, 1987, and Warner \& Arai, 2001, for literature reviews) also have not provided any frequencies of occurrence for the morae unit when constructing target words and nonwords.

As can be seen from these works, to develop more precise experimental conditions, frequency counts for the phonological units of phonemes, morae, and syllables will have to make a greater contribution to various studies in psychology, linguistics, psycholinguistics, and other related areas in estimating phonological familiarity.

\section{Changes of Japanese Sounds and Spellings}

In the history of the Japanese sound palette, a great alteration occurred through the adoption of various vocabularies from different languages. In the Nara period (A.D. 710-784), Japanese sounds were fundamentally constructed with a consonant and a vowel (Koizumi, 1990; Komatsu, 1981; Kubozono, 1999; Kubozono \& Ota, 1998; Numoto, 1987). There was no need to distinguish between syllables and morae, because they were identical in this period. The first alteration came as a result of the influence of the Chinese language. Three special sounds - the nasal $/ \mathrm{N} /$, the geminate (or voiceless obstruent) $/ \mathrm{Q} /$, and the long vowel $/ \mathrm{R} /$ - were created in the process of adopting Chinese words into the Japanese language. These sounds, which were regarded as independent morae, created a distinctive difference between a mora and a syllable. Sound sequences in which these sounds occur, such as $/ \mathrm{kaN} /, / \mathrm{kaQ} /$, and $/ \mathrm{kaR} /$, are counted as two morae, but only a single syllable.

More recently, additional sounds have come from the adoption of alphabetic languages. These loanwords contained many sounds that could not be easily described in the traditional Japanese sound system. As a result, the Japanese developed ways to present the specific sounds of loanwords, using katakana. Kokuritsu Kokugo Kenkyujo [or the National Institute for Japanese Language] (1983) found 162 loanwords that could be written in two ways. Endo (1989) has provided a variety of examples, such as アクセサリー/akusesariR/and アクセサリ/akusesari/ for accessories, ウェーブ /werbu/ and ウエーブ /uerbu/ for wave, ウィンドー/windoR/and ウインドウ/uindou/ for window, アマチア /amacjia/2 and アマチュア /amact jua/ for amateur. The introduction of dual (or even triple) spellings into the Japanese vocabulary has been accelerated, especially in the areas of sports, computers, fashion, and the sciences. Even vocabulary entries in various Japanese dictionaries have a variety of katakana spellings for loanwords (Endo, 1989). As such, in daily Japanese publications, various katakana spellings have been used to describe the same loanwords beyond the limits of the basic 100 morae and three special sounds (see Appendix A).

Responding to this massive adoption of alphabetic loanwords, the Government of Japan (1991) officially declared a list of 33 additional morae (see Appendix B) to be used for presenting these loanwords. This administrative decision implies an official acceptance of katakana multiple spellings for alphabetic loanwords. Except for /wu/ (ヴ), the remaining 32 morae are all contracted sounds, such as $/ \mathrm{fo} /$ in フォーク for fork, / $\mathrm{kwo} /$ in クォーツ for quartz, and /vwe/ in ヴェール for veil, which were created to describe more accurately the sounds of foreign words. The type and token frequencies of 100 basic morae, the special sounds of $/ \mathrm{N} /, / \mathrm{Q} /$, and $/ \mathrm{R} /$, and 33 additional morae (a total of 136 morae) are outlined in Appendixes $\mathrm{A}$ and $\mathrm{B}$.

\section{Japanese Sound Structure}

Japanese phonemes, morae, and syllables can be portrayed in a single hierarchical structure (Haraguchi, 1996; Kubozono, 1989, 1995, 1999, 2002; Kubozono \& Ota, 1998; Terao, 2002). As is shown in Figure 1, the lowest phonological level is the phonemic level, representing consonants (C), semivowels (S), and vowels (V). The next level is the moraic level. The first mora $\left(\mu_{1}\right)$ is constructed from four different combinations: a single vowel $(\varphi \mathrm{V}$, such as $/ \mathrm{a} /, / \mathrm{e} /$, and $/ \mathrm{o} /)$, a consonant and a vowel (CV, such as $/ \mathrm{ka} /, / \mathrm{se} /$, and $/ \mathrm{mu} /$ ), a semivowel and a vowel (SV, such as /ja/,/ju/, and /wa/), and a consonant, a semivowel, and a vowel (CSV, such as /t ja/, /pjo/, and $/ \mathrm{mju} /$ ). The second mora $\left(\mu_{2}\right)$ is represented by four special sounds: two consonants, represented by $/ \mathrm{N} /$ or $/ \mathrm{Q} /$, and two vowels represented by $/ \mathrm{R} /$ and $/ \mathrm{J} /$. The dual vowels, such as /ae/, /oi/, and /ou/, are described by a vowel plus $/ \mathrm{J} /$.

The CV-structured morae are also considered to be light syllables; in this sense, these phonetic combinations are classified as syllables, as well as morae. The highest level in the figure is the syllable level, which involves a combination of the first and the second morae $\left(\mu_{1}+\mu_{2}=\sigma\right)$. These combinations are termed heavy syllables. For example, a CVN syllable $/ \mathrm{kaN} /$ consists of three phonemes $(/ \mathrm{k} /, / \mathrm{a} /$, and $/ \mathrm{N} /)$, two morae $(/ \mathrm{ka} /$ and $/ \mathrm{N} /$ ), and one syllable $/ \mathrm{kaN} /$. It is also possible to create a long single syllable, such as CSVRN, as in /t jaRN/, and CSVRQ, as in /pjuRQ/ (see more details in Matsuzaki, 1994), but frequencies related to combinations of two special sounds are excluded in this study, due to the rarity of their occurrence. On the basis of these classifications, the present study calculated frequencies of phonemes, morae, and syllables. 


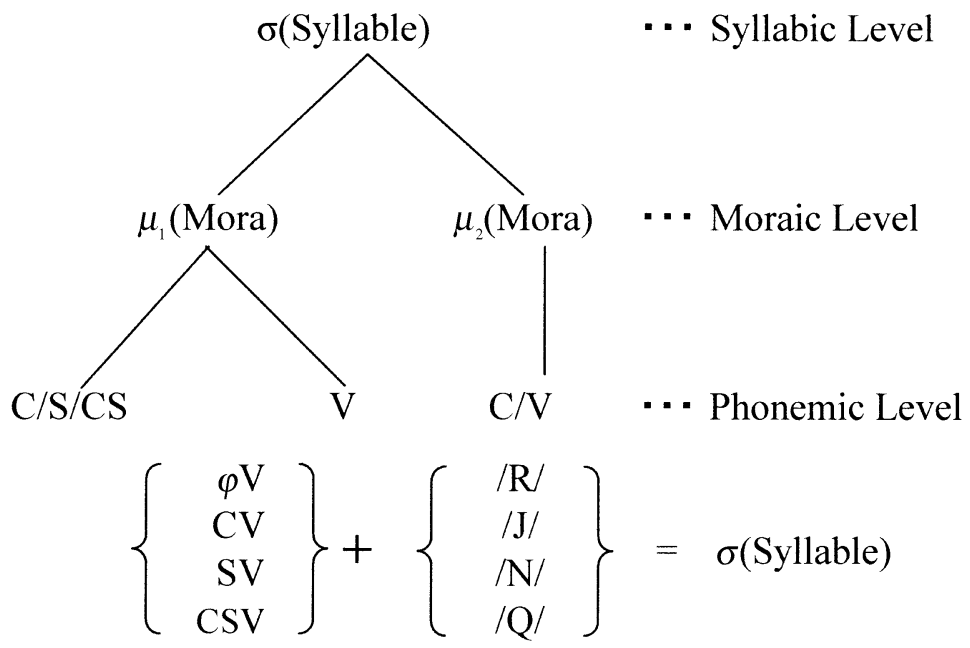

Figure 1. Phonological structure of Japanese syllables.

\section{Kana Type and Token Frequencies}

As a result of the word printed frequency index created by Amano and Kondo (2000), a very large lexical corpus of 341,771 words was established from newspapers containing 287,792,797 words, all of which were taken from the Asahi newspaper printed from 1985 to 1998. At present, this is the largest and the most up-todate word corpus created from calculating the word frequency of occurrence in Japanese written texts. Thus, the present study used this database to calculate frequencies of phonemes, morae, and syllables. The programming language of MacJPerl 5.15r4J for Macintosh was used to run a calculation procedure.

When referring to frequency of occurrence, two different frequencies are used: type and token. Type frequency counts a word once. For example, according to the database (Amano \& Kondo, 2000), /keitai/ has four distinguished lexical meanings: 6,457 times for 携带 (portable), 3,980 for 形態 (form), 58 for 継体 (succession), and 1 for 敬体 (polite form). Whereas the value of the token frequency for / keitai/ is 10,496, the value of type frequency for this sound remains as 4 . Likewise, a mora $/ \mathrm{ke} /$ is counted 4 times for type frequency, whereas token frequency yields a value of 10,496 for $/ \mathrm{ke} /$. A phonemic (a single $\mathrm{V}$ ) or a moraic ( $\varphi \mathrm{V}$ type) frequency of $/ \mathrm{i} /$ for the sound /keitai/ is counted 8 times (/i/ phonemes twice in each of four homophonic words) for type frequency and 20,992 for token frequency. It is interesting to compare frequency counts in print and sound. The /keitai/ for succession, written with two kanji (継体), has a very small value of 4 for token frequency in print, but a very large value of 10,496 for token frequency in sound. As such, this word is very unfamiliar in the written form but is extremely familiar in the phonological form.

In order to investigate the differences in frequency of occurrence, the type and token frequencies for 101 basic morae (or kana), are plotted in Figure 2. A majority of morae are within a range of $0-5,000,000$ for token frequency and $0-10,000$ for type frequency. The largest value of token frequency was given to $\nmid(/ \mathrm{i} /, \varphi \mathrm{V}$ type $)$. The largest value of type frequency was given to $ウ(/ \mathrm{u} /$, $\varphi \mathrm{V}$ type). It is rather surprising that the special sound $/ \mathrm{N} /$ appeared to be very high in both type and token frequencies. As was explained for the alteration of Japanese sounds, the $/ \mathrm{N} /$ sound appeared in the process of adopting various Chinese words, so that it is often included in many Japanese words (see details in Kubozono \& Ota, 1998; Matsuzaki, 1994; Numoto, 1987). Although the $/ \mathrm{N} /$ sound is identified as special, it is often seen in Japanese words. Vowels of /o/ and /a/, which are regarded as the first to be acquired among Japanese children, do not appear as often as an independent kana (mora) unit of $\varphi \mathrm{V}$.

As is shown in Figure 2, Pearson's correlation was significantly high between the two frequency counts $(n=$ $101 ; r=.908, p<.01$ ). This result indicates that the frequency indexes of token and type for 101 morae exhibit almost no difference. A linear regression line is drawn on a plotted graph $\left(y=485.15 x-140,755, R^{2}=.824\right)$. The resulting correlation was calculated on the basis of mora units presented by kana symbols, so that phonemic frequencies are not taken into consideration. In the present study, token frequency is used to calculate frequency counts of phonemes, morae, and syllables. Thus, frequency of occurrence refers hereafter to token frequency, unless otherwise specified.

\section{Five Vowels $(\varphi \mathbf{V})$ and $(+\mathbf{V})$}

Simply speaking, vowels and consonants are distinguished by whether or not they can function as independent morae/syllables. According to this definition, there are five vowels in Japanese: /a/, /i/, /u/, /e/, and /o/. When they are independent morae/syllables, their phonological structure is described as $\varphi \mathrm{V}$. Since semivowels $/ \mathrm{w} /$ and $/ \mathrm{y} /$ cannot be independent morae/syllables by themselves and share characteristics of consonants, they 


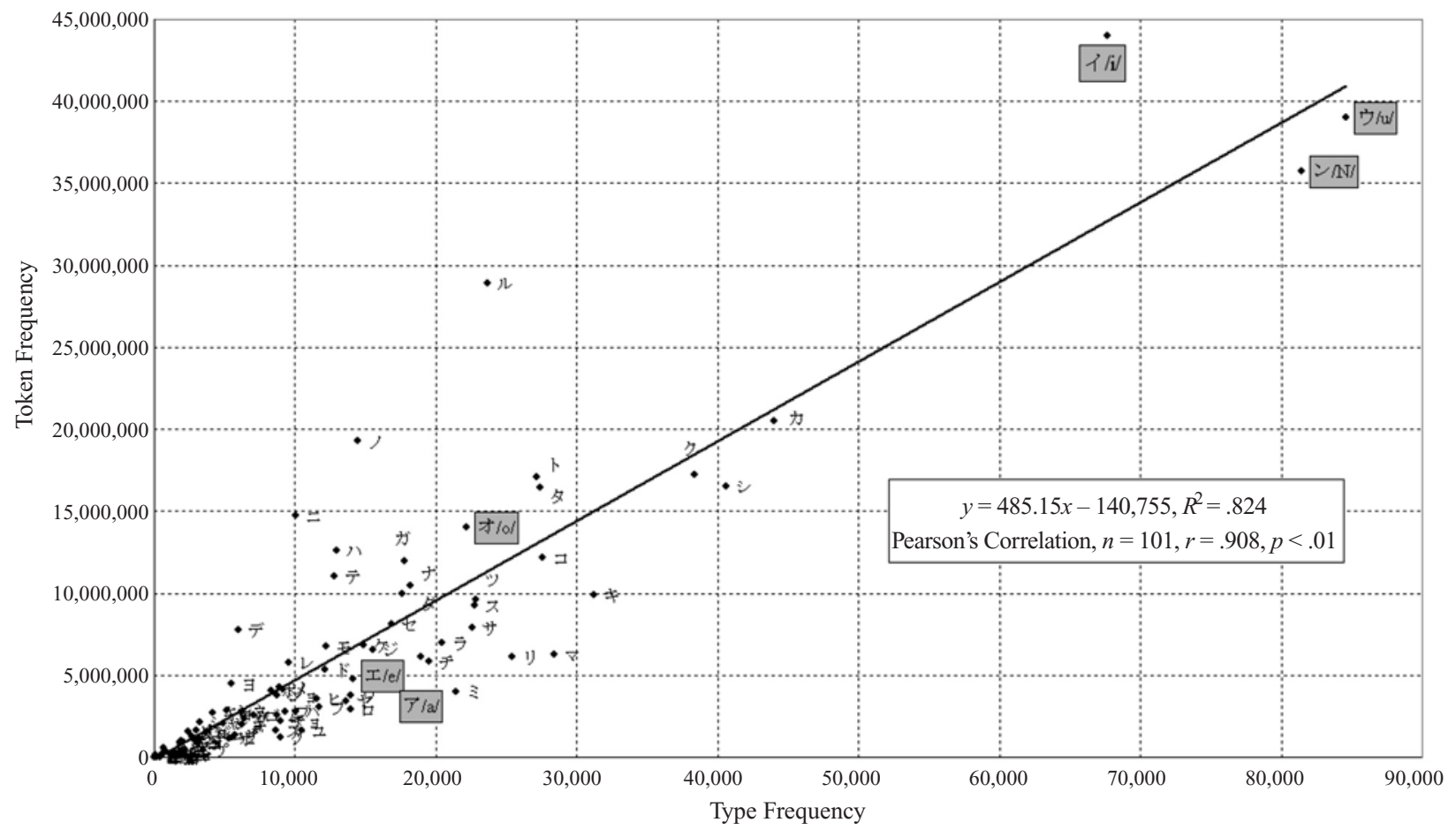

Figure 2. Plotting of mora type and token frequencies.

are categorized slightly differently than regular vowels. The special sounds $/ \mathrm{N} /, / \mathrm{Q} /, / \mathrm{R} /$, and $/ \mathrm{J} /$ are, however, considered as single morae.

Table 1 shows frequency counts of the five Japanese vowels as single moraic (kana) units. Among them, $/ \mathrm{i} /$ was the most frequently used vowel in the form of $\varphi \mathrm{V}$, having a frequency value of $43,985,426$ times, or $40.72 \%$. This may be caused by the ending of adjective inflections, which are very often a single phoneme and a mora $/ \mathrm{i} /$, such as /nemui/ (sleepy in English), /samui/ (cold), and /amai/ (sweet). The second most frequently used vowel was $/ \mathrm{u} /$, having a frequency value of 39,052,254 times, or $36.16 \%$. Again, this may be caused partly by verb inflections, such as /utau/ (to sing), /arau/ (to wash), and /warau/ (to laugh). The least frequently used vowel was $/ \mathrm{e} /$ at $4.41 \%$.

However, when the frequencies of the possible appearances of vowels $(+\mathrm{V})$ are counted, all five vowels seem to have a much smaller range from $58,172,645$ occurrences, or $10.94 \%$, for /e/ to $124,790,724$ times, or $23.47 \%$, for $/ \mathrm{u} /$. The vowels $/ \mathrm{a} /$ and $/ \mathrm{o} /$ were less frequently seen in the $\varphi \mathrm{V}$ structure, but in the $+\mathrm{V}$ structure their frequency increased to $23.42 \%$ for $/ \mathrm{a} /$ and $20.63 \%$ for $/ \mathrm{o} /$. Therefore, once all sound combinations were considered, /a/, /i/, /u/, and /o/ showed similar frequencies of occurrence. Yet /e/ remained the least frequently used vowel among the five.

\section{Consonants (C) and Their Combinations With Vowels (CV)}

As can be explained by the changes in Japanese sounds, the combinations of a consonant and a vowel are considered as typical Japanese morae, evident in the large total frequency of $386,480,338$. There are 12 consonants in the $\mathrm{CV}$ structure shown in Table 2 . Among them, $/ \mathrm{k} /$ was the most frequently used consonant, totaling 66,644,942 times,

Table 1

Frequency Counts of Vowels $(\varphi \mathrm{V}$ and $+V)$

\begin{tabular}{crcrcc}
\hline & \multicolumn{2}{c}{$\varphi$ V Type } & & \multicolumn{2}{c}{ All Vowels } \\
\cline { 2 - 3 } \cline { 5 - 6 } Vowel & \multicolumn{1}{c}{ Count } & Frequency $(\%)$ & & Count & Frequency (\%) \\
\hline /a/ & $6,149,909$ & 5.69 & & $124,536,587$ & 23.42 \\
/i/ & $43,985,426$ & 40.72 & & $114,568,843$ & 21.54 \\
/u/ & $39,052,254$ & 36.16 & & $124,790,724$ & 23.47 \\
/e/ & $4,767,153$ & 4.41 & & $58,172,645$ & 10.94 \\
/o/ & $14,053,377$ & 13.01 & & $109,714,325$ & 20.63 \\
Total & $108,008,119$ & 100.00 & & $531,783,124$ & 100.00 \\
\hline
\end{tabular}


Table 2

Frequency Counts of Consonants and Their Clusters (CV)

\begin{tabular}{|c|c|c|c|c|c|c|c|c|c|}
\hline \multirow[b]{2}{*}{ Voice } & \multirow[b]{2}{*}{ Articulation } & \multirow[b]{2}{*}{ Consonant } & \multirow[b]{2}{*}{ Total } & \multirow[b]{2}{*}{$\%$} & \multicolumn{5}{|c|}{ Vowel } \\
\hline & & & & & $/ \mathrm{a} /$ & /i/ & $/ \mathrm{u} /$ & $/ \mathrm{e} /$ & $10 /$ \\
\hline \multirow[t]{5}{*}{ Voiceless } & Stop & $/ \mathrm{p} /$ & $2,312,976$ & 0.60 & 984,460 & 192,847 & 445,557 & 182,551 & 507,561 \\
\hline & & $/ \mathrm{t} /$ & $60,002,817$ & 15.53 & $16,442,465$ & $5,808,199$ & $9,612,206$ & $11,037,767$ & $17,102,180$ \\
\hline & & $/ \mathrm{k} /$ & $66,644,942$ & 17.24 & $20,530,065$ & $9,926,212$ & $17,211,261$ & $6,823,149$ & $12,154,255$ \\
\hline & Fricative & $/ \mathrm{s} /$ & $46,153,365$ & 11.94 & $7,932,086$ & $16,518,016$ & $9,271,734$ & $8,127,590$ & $4,303,939$ \\
\hline & & $/ \mathrm{h} /$ & $24,536,108$ & 6.35 & $12,594,714$ & $3,554,252$ & $3,067,681$ & $1,254,559$ & $4,064,902$ \\
\hline \multirow[t]{7}{*}{ Voiced } & Stop & $/ \mathrm{b} /$ & $9,383,168$ & 2.43 & $2,749,654$ & $1,177,824$ & $2,758,994$ & $1,591,698$ & $1,104,998$ \\
\hline & & $/ \mathrm{d} /$ & $23,005,066$ & 5.95 & $9,953,427$ & - & - & $7,744,822$ & $5,306,817$ \\
\hline & & $/ g /$ & $20,094,629$ & 5.20 & $11,996,376$ & $2,009,223$ & $1,210,586$ & $2,328,945$ & $2,549,499$ \\
\hline & Fricative & $|z|$ & $12,163,220$ & 3.15 & $1,384,993$ & $6,550,231$ & $1,644,763$ & $1,646,454$ & 936,779 \\
\hline & Nasal & $/ \mathrm{m} /$ & $23,748,918$ & 6.14 & $6,289,027$ & $3,972,466$ & $2,577,386$ & $4,118,162$ & $6,791,877$ \\
\hline & & $/ \mathrm{n} /$ & $47,766,161$ & 12.36 & $10,498,607$ & $14,757,618$ & 411,356 & $2,771,906$ & $19,326,674$ \\
\hline & Liquid & $/ \mathrm{r} /$ & $50,668,968$ & 13.11 & $6,947,107$ & $6,116,529$ & $28,899,891$ & $5,777,889$ & $2,927,552$ \\
\hline Total & & & $386,480,338$ & 100.00 & $108,302,981$ & $70,583,417$ & $77,111,415$ & $53,405,492$ & $77,077,033$ \\
\hline
\end{tabular}

Note-The stop /t/ with /i/ is represented by /cji/ (see Appendix A), although it is not indicated in Table $2 . / \mathrm{z} /$ is pronounced $/ \mathrm{zj} /$ or $/ \mathrm{dj} / \mathrm{when}$ it is combined with /i/, but in this study /zi/ is used to represent this mora (see Appendix A). In this table, / $/$ / is categorized as a fricative, although $/ z /$ is pronounced either as a fricative or an affricate allophonically.

or $17.24 \%$ of the total CV frequency. The second most frequently used consonant was $/ \mathrm{t} /$, appearing $60,002,817$ times, or $15.53 \%$. The third was $/ \mathrm{r} /$ at $50,668,968$ times, or $13.11 \%$. The consonant $/ \mathrm{p} /$ showed the lowest frequency of $2,312,976$ times, or $0.60 \%$. Following this, $/ \mathrm{b} /$ was counted $9,383,168$ times, or $2.43 \%$. As is shown in Table 2,/ru/ was the most frequently used among CV morae (or syllables, since they are identical), with a frequency count of $28,899,891$ times. This is because inflections of verbs are often $/ \mathrm{ru} /$. The second most frequently used mora was $/ \mathrm{ka} /$, being recorded 20,530,065 times. The third was $/ \mathrm{no} /$, the fourth was $/ \mathrm{ku} /$, and the fifth was $/$ to/. It should be noted that $/ \mathrm{z} /$ is pronounced $/ \mathrm{zj} /$ or $/ \mathrm{dj} /$ when it is combined with the vowel $/ \mathrm{i} /$. However, in the present study, /zi/ is used to represent this mora (see Appendix A). Interestingly, the frequency of /zi/ is high-6,550,231 times of occurrence, far beyond the frequencies of other vowel combinations with $/ \mathrm{z} /$.

\section{Frequencies Involving Semivowels (S)}

In Japanese phonology, from the perspective of the kana script, $\varphi \mathrm{V}$ and $\mathrm{CV}$ mora/syllable sounds are referred to as direct sounds (tan'on in Japanese). Since SV and CSV mora/syllable sounds are represented by two kana symbols (the second is written in a smaller size kana), such as キャ $(/ \mathrm{kja} /)$, ショ $(/ \mathrm{sjo} /)$, and ニュ $(/ \mathrm{nju} /)$, these are called contracted sounds, or palatalized sounds (yoo'on in Japanese). The contracted sounds are constructed with the semivowel $/ \mathrm{j} / 3$ in their moraic structures, which appear with three vowels- $/ \mathrm{a} /, / \mathrm{u} /$, and $/ \mathrm{o} /$. The vowels $/ \mathrm{i} /$ and /e/ in contracted morae do not appear in Japanese (they do not contain frequency counts) and are thus called open spaces (akima). They are indicated by - in Table 3.

Apart from this, both the direct and the contracted sounds are identical in terms of the use of a single mora and a single syllable. From the perspective of the kana

Table 3

Frequency Counts of Semivowels and Contracted Sounds (SV and CSV)

\begin{tabular}{|c|c|c|c|c|c|c|c|c|c|c|}
\hline \multirow{2}{*}{$\begin{array}{l}\text { Phonemic } \\
\text { Structure }\end{array}$} & \multirow[b]{2}{*}{ Voice } & \multirow[b]{2}{*}{ Articulation } & \multirow[b]{2}{*}{ Phonemes } & \multirow[b]{2}{*}{ Total } & \multirow[b]{2}{*}{$\%$} & \multicolumn{5}{|c|}{ Vowel } \\
\hline & & & & & & /a/ & $/ \mathrm{i} /$ & $/ \mathrm{u} /$ & $/ \mathrm{e} /$ & $/ \mathrm{o} /$ \\
\hline \multirow[t]{2}{*}{ SV } & Voiced & Semivowel & $/ \mathrm{w} /$ & $3,777,201$ & 28.37 & $3,777,201$ & - & & - & \\
\hline & & & $/ \mathbf{j} /$ & $9,536,584$ & 71.63 & $3,432,278$ & - & $1,620,066$ & - & $4,484,240$ \\
\hline \multirow[t]{11}{*}{$\operatorname{CSV}(\mathrm{C}+/ \mathrm{j} /+\mathrm{V})$} & Voiceless & Stop $+/ \mathbf{j} /$ & $/ \mathrm{pj} /$ & 155,382 & 0.65 & 95 & - & 29,907 & - & 125,380 \\
\hline & & & $/ \mathrm{tj} /$ & $3,401,638$ & 14.18 & 199,251 & - & 995,900 & - & $2,206,487$ \\
\hline & & & $/ \mathrm{kj} /$ & $3,817,809$ & 15.92 & 166,750 & - & 929,206 & - & $2,721,853$ \\
\hline & & Fricative $+/ \mathbf{j} /$ & $/ \mathrm{s} \mathbf{j} /$ & $8,737,457$ & 36.44 & $2,138,138$ & - & $2,858,438$ & - & $3,740,881$ \\
\hline & & & $/ \mathrm{hj} /$ & 634,527 & 2.65 & 53,284 & - & 3,304 & - & 577,939 \\
\hline & Voiced & Stop $+/ \mathbf{j} /$ & $/ \mathrm{bj} /$ & 179,278 & 0.75 & 511 & - & 16,016 & - & 162,751 \\
\hline & & & $/ \mathrm{g} \mathrm{j} /$ & $1,011,811$ & 4.22 & 59,424 & - & 15,343 & - & 937,044 \\
\hline & & Fricative $+/ \mathrm{j} /$ & $/ \mathrm{zj} /$ & $3,712,578$ & 15.48 & 188,263 & - & $1,482,387$ & - & $2,041,928$ \\
\hline & & $\mathrm{Nasal}+/ \mathbf{j} /$ & $/ \mathrm{mj} /$ & 63,922 & 0.27 & 14,646 & - & 15,494 & - & 33,782 \\
\hline & & & $/ \mathrm{nj} /$ & 460,379 & 1.92 & 3,087 & - & 446,886 & - & 10,406 \\
\hline & & Liquid $+/ \mathbf{j} /$ & $/ \mathrm{rj} /$ & $1,806,101$ & 7.53 & 50,769 & - & 214,108 & - & $1,541,224$ \\
\hline
\end{tabular}

Note-The overall total of SV frequency is $13,313,785$, whereas the overall total of CSV frequency is $23,980,882$. The total frequency of $/ \mathrm{j} /$ is $31,711,365$, whereas the total frequency of $/ \mathrm{w} /$ is $3,777,201$. 
script, the contracted sounds are combinations of 11 consonants with $/ \mathrm{j} /$, which are described by three small kana, ヤ $(/ \mathrm{ja} /)$, 그 $(/ \mathrm{ju} /)$, and $\exists(/ \mathrm{jo} /)$, depending on the following vowels (for details, see Amanuma, Otsubo, \& Mizutani, 1996). All these contracted sounds contain semivowels within a phonological structure. It should be noted that the sounds $/ \mathrm{dj} /$ and $/ \mathrm{zj} /$ are not distinguished in standard Japanese, although they could be written differently in kana. Thus, they are treated as the same sound, as represented by $/ \mathrm{zj} /$. This resulted in 11 consonants with the semivowel $/ \mathbf{j} /$ in contracted sounds shown in Table 3 .

There are two semivowels, $/ \mathrm{w} /$ and $/ \mathrm{j} /$. As is indicated in Table $3, / \mathrm{j} /$ had a much higher frequency $(9,536,584$ times) than $/ \mathrm{w} /(3,777,201$ times $)$. Among morae of the SV structure, /jo/ had the highest frequency $(4,484,240$ times). Only $/ \mathbf{j} /$ is combined with consonants, and as is shown in Table 3, there are $11 \mathrm{CS}$ combinations. The combination /sj/ appeared $8,737,457$ times, or $36.44 \%$. The CS combination $/ \mathrm{kj} /$ was the second most frequent, occurring 3,817,809 times. The least used CS combination was $/ \mathrm{mj} /$, appearing only 63,922 times, or $0.27 \%$. The second least used CS combination was $/ \mathrm{pj} /$, counted 155,382 times, or $0.65 \%$. Among the CSV moraic units, /sjo/ was the most frequently used, appearing 3,740,881 times. The mora /sju/ was the second most frequently used, appearing 2,858,438 times. The third was $/ \mathrm{kjo} /$ at $2,721,853$ times. In contrast, /pja/ was the least frequent, being counted only 95 times.

Vowel combinations with $/ \mathrm{w} /$ are limited to $/ \mathrm{a} /$. According to Okumura (1977), / kwa/ and /gwa/ were used in old Japanese but disappeared by the end of the 16th century. However, /wi/, /we/, and /wo/, including / kwa/, /kwi/, /kwe/, /kwo/, /gwa/, /vwa/, /vwi/, /vwe/, and /vwo/, are now revived and used only for newly adopted katakana loanwords. These morae are included as a part of the aforementioned officially announced 33 sounds (see Appendix B). In contrast, / $\mathbf{j}$ / appears frequently in Wago (words of Japanese origin) and Kango (words of Chinese origin). The sounds $/ \mathrm{ja} /, / \mathrm{ju} /$, and $/ \mathrm{jo} /$ are used following various consonants, such as /p/,/s/, /h/, /b/ /g/, $/ \mathrm{z} /, / \mathrm{m} /$, and $/ \mathrm{n} /$ in both Wago and Kango.

\section{Thirty-Three Additional Morae Used for Alphabetic Loanwords}

According to the 1991 Japanese government guidelines, 33 additional morae (or kana), ${ }^{4}$ along with the 100 basic kana and 3 kana for three special sounds, are officially specified for describing alphabetic loanwords (Tamaoka \& Miyaoka, 2003). The type and token frequencies of these 33 morae, used only for alphabetic loanwords, are reported in Appendix B. These additional morae showed a wider range of token frequencies. The most frequently used mora was /ti/ (テイ), being registered 66,313 times. In fact, $/ \mathrm{ti}$ / is used for presenting common loanwords, such as ティーム (/tirmu/, for team), ティー (/tikR/, for tea), パーティー (/partiR/, for party), and ボランティア (/borantia/, for volunteer). According to the basic Japa- nese sound system (i.e., the 101 basic morae), /cji/ for 于 (allophone of the $/ \mathrm{t} /$-line mora sounds) was not distinguished from the consonant /t/ for /ta/ (タ), /tu/ (ツ), /te/ (テ), and /to/ (ト): These five morae are all classified as /t/-plus-vowel CV morae. However, as Ishihara (1997) has pointed out, modern Japanese can clearly distinguish ミルクティー (/mirukutiR/, for milk tea), from ミルクチー (/mirukucjir/). Thus, they can easily identify the difference between /ti/ and /cji/. Furthermore, Ishihara (1997) stated that Japanese also distinguish ツイ (/ci/) from テイ (/ti/) and チ (/cji/) in both speaking and listening. For example, the name of former Russian president Yeltsin is described by エリツィン (/ericiN/), rather than エリチン (/ericjin/) or エリティン (/eritiN/). A majority of native Japanese speakers can correctly perceive and properly pronounce them as different sounds.

In contrast, the morae, including the contracted sounds of $/ \mathrm{kw} /$ with vowels—/kwa/ (クア), / kwi/ (クイ), /kwe/ (クエ), and $/ \mathrm{kwo} /$ (クオ)—are rarely seen. The mora /kwu/ (クウ) can exist by simply adding the vowel /u/. However, instead, /ku/ (ク) is used, so / $\mathrm{kwu} /$ does not appear in Japanese. Although these are new sounds, they follow the Japanese phonological structure of CSV depicted in Figure 1. The least frequently used mora was /kwe/, which appeared only twice. In the lexical corpus of Amano and Kondo (2000), the mora / kwe/ was used only for the English loanword sequence, presented as シークェンス (/sirkwensu/). Similarly, /kwi/ was the second least used mora, appearing 20 times. Examples of /kwi/ include クイーン (/kwiRN/, for queen) and クインテット (/kwinterto/, for quintet $)$. The mora /kwa/ was used only 21 times: 12 for quartet, presented as クアルテット (/kwaruterto/), and 9 for esquire, presented as エスクアイア (/esukwaia/). The mora /kwo/ has a slightly higher frequency of 85 . This was used for loanwords such as quarter, presented as クォーター

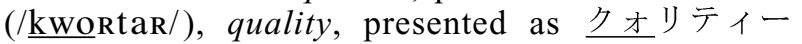
(/kworitiR/), and quarterly, presented as クォータリー (/kwortarik/). Judging from these examples, $/ \mathrm{kw} /$ is basically used to describe the English spelling $q u$, which also represents the sound $/ \mathrm{kw} /$ in English.

Japanese people educated since the Second World War study English for at least 3 years from Grades 7-9, and usually for 6 years up to Grade 12 . As the consonant $/ \mathrm{v} /$ is commonly seen in English, some new morae have started being used to approximate this English sound. These have included /va/ (ヴァ), /vi/ (ヴィ), /vu/ (ヴ), /ve/ (ヴェ), and /vo/ (ヴオ) for describing the /v/ sound in loanwords. Among them, /vi/ is the most common mora, appearing 733 times as examples in such words as ヴェニス (/venisu/, for Venice), ソヴィエト (/sovieto/, for Soviet), ダイヴィング (/daivingu/, for diving), and リヴィング (/rivingu/, for living). As all these examples indicate, the English spelling of $v i$ is described using the contracted sound of / vi/ in Japanese. Since these words had previously been written as /bi/ (ビ), modern Japanese has begun to distinguish $/ \mathrm{v} /$ and $/ \mathrm{b} /$ when adopting 
alphabetic loanwords. Yet native Japanese speakers most probably pronounce a fricative consonant /V/ like a stop consonant /b/ (Matsuzaki, 1993), although they distinguish /v/ from /b/ in the katakana script.

Another interesting aspect of the new 33 morae is the existence of the consonant /f/, which is not described in the table of 101 basic Japanese morae. Jouo (1977) has claimed that a combination of $/ \mathrm{f} / 5 \mathrm{plus} / \mathrm{a} /$ is already accepted by native Japanese speakers to describe alphabetic loanwords as examples of ファイト (/faito/, for fight) and ファースト (/farsuto/, for first). Koizumi (1989, 1990) and Ishihara (1995) also have suggested that /f/ is an independent consonant within the collection of Japanese sounds, although it is not included in the table of 101 fundamental Japanese morae. In fact, according to our index of frequency counts, the consonant /f/ extended to other vowels and is now found in $/ \mathrm{fa} /$ (ファ), /fi/ (フイ), /fe/ (フェ), and /fo/ (フォ). In comparison with other additional morae (see Appendix B), the frequencies of these morae are relatively high at 60,484 times for /fa/, 50,615 times for /fi/, 16,129 times for /fe/, and 31,399 times for /fo/. Since frequencies concerning the combination of /f/ plus vowels are high among the 33 morae, the consonant/f/ seems to have infiltrated into Japanese sounds. However, Ishihara (1995) has noted that, in general, native Japanese speakers have not yet been able to distinguish /fa/ from /ha/, /fe/ from /he/, and $/$ fo/ from $/$ ho/ in speaking (i.e., production).

\section{Syllables With Dual Vowels/Diphthongs (+VJ) and Long Vowels (+VR)}

As is depicted in Figure 1, the structure of CVV (both dual vowels/diphthongs of CVJ and long vowels of CVR) is regarded as two morae, $\mathrm{CV}$ and $\mathrm{V}$ ( $\mathrm{V}$ can be either $/ \mathrm{J} /$ or $/ \mathbf{R} /$ ), but as a single syllable. The frequency of occurrence for these sounds is shown in Table 4. Taking two vowels for $\mathrm{V}_{1} \mathrm{~V}_{2}$ positions that are interchangeable, there were 25 different combinations of the two vowels. When the first and the second vowels were the same, they were considered long vowels. In Table 4, these were shown in five diagonal cells. When the first and the second vow- els differed, they were recorded as dual vowels, totaling 20 cases. Although the 25 two-vowel combinations added up to a total frequency of $72,657,680$ times, these sounds were not unusual in terms of occurrence in Japanese words. It should be noted that a word such as tousan, meaning father, is very often pronounced as /torsan/ with a long vowel, not two vowels. Furthermore, vowel combinations of -ei and -ou are often pronounced as long vowels. However, since the original database of Amano and Kondo (2000) does not distinguish whether or not these two consecutive vowels are long vowels, these differences are not taken into consideration in the present frequency counts.

The total frequency of the five long vowels was 3,600,096 times. Among the five long vowels, /aR/ showed the highest frequency of $1,236,532$ times, $1.70 \%$ of the total dual/long-vowel frequency, or $34.35 \%$ of the total for the five long vowels. The long vowel of /iR/ was the second highest in frequency, appearing 733,413 times, or $1.01 \%$ (or $20.37 \%$ of the five vowels). Third was $/ \mathrm{eR} /$, appearing 634,079 times, or $0.87 \%$ (or $17.61 \%$ of the five vowels), and fourth was /oR/, appearing 560,222, or $0.77 \%$ (or $15.56 \%$ of the five vowels). The lowest was $/ \mathrm{uR} /$, which occurred just 435,850 times, or $0.60 \%$ (12.11\% of the five vowels). However, it should be noted that, due to difficulties involved in the differentiation of words' moraic segmentations, the token and type frequencies of a long vowel / $\mathbf{R} /$ include two continuous vowels, such as in /baai/, meaning case, which is usually segmented into two morae of /ba/ and /ai/.

Twenty dual vowels were counted up to $69,057,584$ times. Among them, the highest frequency rate was /ou/, showing 27,448,213 times, or $37.78 \%$. The second was /ai/ at $17,710,419$ times, or $24.38 \%$. The third was /ei/ at $12,199,230$ times, or $16.79 \%$. Surprisingly, these three combinations make up $78.95 \%$ of all the 25 combinations. More specifically, the term dual vowel, or diphthong, refers to two continuous vowels (e.g., /ai/, /au/, $/ \mathrm{oi} /$ ) that change from an open vowel (i.e., /a/, /o/) to a closed vowel (i.e., $/ \mathbf{i} /, / \mathrm{u} /$ ). The vowel /e/ is between the open and the closed vowels. Two continuous vowels, such as /ia/, /uo/, and /io/, which change from a closed

Table 4

Frequency Counts of Dual Vowels $(+/ \mathrm{J} /)$ and Long Vowels $(+/ \mathrm{R} /)$

\begin{tabular}{|c|c|c|c|c|c|c|c|c|c|c|c|c|c|c|c|}
\hline \multirow{3}{*}{$\begin{array}{l}\text { Following } \\
\text { Vowels } \\
(/ \mathrm{J} / \text { or } / \mathrm{R} /)\end{array}$} & \multicolumn{15}{|c|}{ Previous Vowels $(\mathrm{V}+)$} \\
\hline & \multicolumn{3}{|c|}{$/ \mathrm{a} /$} & \multicolumn{3}{|c|}{ /i/ } & \multicolumn{3}{|c|}{$/ \mathrm{u} /$} & \multicolumn{3}{|c|}{ /e/ } & \multicolumn{3}{|c|}{$/ \mathrm{o} /$} \\
\hline & Pair & Count & $\%$ & Pair & Count & $\%$ & Pair & Count & $\%$ & Pair & Count & $\%$ & Pair & Count & $\%$ \\
\hline$/ \mathrm{a} /$ & aR & $1,236,532$ & 1.70 & ia & $1,049,302$ & 1.44 & ua & 246,548 & 0.34 & ea & 493,440 & 0.68 & oa & 78,570 & 0.11 \\
\hline /i/ & ai & $17,710,419$ & 24.38 & iR & 733,413 & 1.01 & ui & $2,048,443$ & 2.82 & ei & $12,199,230$ & 16.79 & oi & $1,306,835$ & 1.80 \\
\hline$/ \mathrm{u} /$ & $\mathrm{au}$ & 994,228 & 1.37 & iu & $1,223,360$ & 1.68 & UR & 435,850 & 0.60 & $\mathrm{eu}$ & 12,575 & 0.02 & ou & $27,448,213$ & 37.78 \\
\hline$/ \mathrm{e} /$ & $\mathrm{ae}$ & $1,329,310$ & 1.83 & ie & 561,233 & 0.77 & ue & 695,410 & 0.96 & eR & 634,079 & 0.87 & oe & 369,639 & 0.51 \\
\hline$/ 0 /$ & ao & 372,343 & 0.51 & io & 411,375 & 0.57 & uo & 255,949 & 0.35 & eo & 251,162 & 0.35 & OR & 560,222 & 0.77 \\
\hline Total & & $21,642,832$ & 29.79 & & $3,978,683$ & 5.48 & & $3,682,200$ & 5.07 & & $13,590,486$ & 18.70 & & $29,763,479$ & 40.96 \\
\hline
\end{tabular}

Note-The five shaded diagonal cells are long vowels. The overall total of frequencies in Table 4 is 72,657,680. Specifically, the term dual vowel, or diphthong, refers to two continuous vowels (e.g., /ai/, /au/, /oi/) that change from an open vowel (i.e., /a/, /o/) to a closed vowel (i.e., /i/, /u/). The vowel/e/ is between the open and closed vowels. Two continuous vowels, such as /ia/, /uo/, and /io/ which change from a closed vowel to an open vowel, are considered to be two independent vowels (see Kubozono, 1999). 
vowel to an open vowel, are considered to be two independent vowels (see Kubozono, 1999). There are 8 dual vowels out of 20 combinations based on this definition (i.e., /ai/,/au/,/ae/,/oi/,/ou/,/oe/,/ei/, and/eu/), which were counted $61,370,449$ times, or $84.48 \%$ of the 20 vowel combinations. This suggests that the majority of two continuous different vowel combinations are opento-closed dual vowels. Since Table 4 provides frequency counts for all possible consecutive vowels, all the different two-vowel combinations are labeled "dual vowels" in Table 4. Thus, the difference between continuous (i.e., dual vowel or diphthong) and independent vowels should be carefully treated when using frequency counts in Table 4.

Long vowels placed after consonants $(\mathrm{C}+)$, semivowels $(\mathrm{S}+)$, and consonants plus semivowels (CS+) are considered as syllabic units, as is depicted in Figure 1. Their token frequencies are shown in Table 5. Among these combinations, /par/ appeared most frequently, at 407,453 times. The second was /taR/ at 229,783 times. The third was $/ \mathrm{meR} /$ at 174,212 times, and the fourth was /riR/ at 157,583 times. The consonant $/ \mathrm{p} /$ was combined most fre- quently with five long vowels and was counted 581,256 times, whereas the second was $/ \mathrm{r} /$ at 507,423 times. Long vowels are also combined with the semivowels $/ \mathrm{w} /$ and $/ \mathrm{j} /$. The semivowel $/ \mathrm{w} /$ is compounded only with $/ \mathrm{aR} /$ and was counted 42,893 times. In contrast, the semivowel $/ \mathrm{j} /$ is combined with three long vowels - / jaR/,/juR/, and /joR/. In addition, various contrastive sounds with $/ \mathrm{j} /$ are also tied with these three different long vowels, shown in Table 5. Among them, the most frequently appearing sound was /njur/ at 72,726 times. The second was /pjuR/ at 28,837 times, and the third was /zjar/ at 21,755 times.

\section{Long Vowels in Katakana Loanwords}

A katakana symbol of - for the long vowel /R/, as in コーヒー (/koRhiR/, meaning coffee $)$, is used for alphabetic loanwords. The total frequency of katakana appearances was $28,464,753$ times in the database of the Asahi newspaper. By counting only katakana, Table 6 provides the top 20 frequently printed katakana. The result is noteworthy in that the special sound of the long vowel / $\mathrm{R} /$ was the highest, appearing $2,860,333$ times, or

Table 5

Frequency Counts of Syllables With Long Vowel/R/ ( + R type)

\begin{tabular}{|c|c|c|c|c|c|c|c|}
\hline & \multicolumn{2}{|c|}{ Total } & \multicolumn{5}{|c|}{ Vowel } \\
\hline & Frequency & $\%$ & /aR/ & $/ \mathrm{iR} /$ & /uR/ & $/ \mathrm{e} /$ & $/ \mathrm{OR} /$ \\
\hline \multicolumn{8}{|c|}{ With Consonants ( $\varphi$ VR or CVR) } \\
\hline$\varphi$ & 229,142 & 6.74 & 51,753 & 31,871 & 1,806 & 50,810 & 92,902 \\
\hline$/ \mathrm{p} /$ & 581,256 & 17.10 & 407,453 & 70,941 & 7,240 & 33,850 & 61,772 \\
\hline$/ \mathrm{t} /$ & 358,111 & 10.54 & 229,783 & 46,703 & 2,489 & 51,418 & 27,718 \\
\hline$/ \mathrm{k} /$ & 309,283 & 9.10 & 128,888 & 31,200 & 17,828 & 63,609 & 67,758 \\
\hline$/ \mathrm{s} /$ & 217,669 & 6.40 & 69,847 & 96,096 & 25,708 & 18,067 & 7,951 \\
\hline$/ \mathrm{h} /$ & 76,375 & 2.25 & 14,443 & 6,388 & 2,517 & 503 & 52,524 \\
\hline$/ \mathrm{b} /$ & 206,895 & 6.09 & 73,329 & 52,467 & 18,442 & 26,756 & 35,901 \\
\hline$/ \mathrm{d} /$ & 78,784 & 2.32 & 33,435 & - & - & 32,034 & 13,315 \\
\hline$/ g /$ & 77,532 & 2.28 & 10,857 & 32,410 & 2,015 & 17,723 & 14,527 \\
\hline$|\mathbf{z}|$ & 65,767 & 1.93 & 13,814 & 43,638 & 1,838 & 518 & 5,959 \\
\hline$/ \mathrm{m} /$ & 236,140 & 6.95 & 33,050 & 6,556 & 10,031 & 174,212 & 12,291 \\
\hline$/ \mathrm{n} /$ & 106,216 & 3.12 & 34,166 & 31,217 & 5,452 & 19,008 & 16,373 \\
\hline$/ \mathrm{r} /$ & 507,423 & 14.93 & 38,329 & 157,583 & 141,091 & 108,136 & 62,284 \\
\hline \multicolumn{8}{|c|}{ With Semivowels (SVR) } \\
\hline$/ \mathrm{w} /$ & 42,893 & 1.26 & 42,893 & - & - & - & - \\
\hline$/ \mathrm{j} /$ & 87,314 & 2.57 & 5,392 & - & 34,678 & - & 47,244 \\
\hline \multicolumn{8}{|c|}{ With Contracted Sounds (CSVR) } \\
\hline$/ \mathrm{pj} /$ & 28,897 & 0.85 & 0 & - & 28,837 & - & 60 \\
\hline$/ \mathrm{tj} /$ & 25,394 & 0.75 & 15,579 & - & 8,055 & - & 1,760 \\
\hline$/ \mathrm{kj} /$ & 8,090 & 0.24 & 0 & - & 7,658 & - & 432 \\
\hline$/ \mathrm{sj} /$ & 20,120 & 0.59 & 5,698 & - & 5,454 & - & 8,968 \\
\hline$/ \mathrm{hj} /$ & 3,127 & 0.09 & 0 & - & 2,824 & - & 303 \\
\hline$/ \mathrm{bj} /$ & 15,460 & 0.45 & 0 & - & 15,440 & - & 20 \\
\hline$/ \mathrm{gj} /$ & 272 & 0.01 & 15 & - & 12 & - & 245 \\
\hline$/ \mathrm{zj} /$ & 32,055 & 0.94 & 21,755 & - & 5,690 & - & 4,610 \\
\hline$/ \mathrm{mj} /$ & 6,387 & 0.19 & 48 & - & 6,339 & - & 0 \\
\hline$/ \mathrm{nj} /$ & 72,922 & 2.15 & 3 & - & 72,726 & - & 193 \\
\hline$/ \mathrm{rj} /$ & 5,634 & 0.17 & 8 & - & 5,587 & - & 39 \\
\hline Total & $3,399,158$ & 100.00 & $1,230,538$ & 607,070 & 429,757 & 596,644 & 535,149 \\
\hline
\end{tabular}

Note-There are more combinations of consonants with $/+\mathrm{R} /$ that are not listed in Table 5 . Thus, the total frequency of a single $/ \mathrm{R} /(3,607,169)$ in Appendix A is higher than the total of $3,399,158$ shown in Table 5 . 
Table 6

The 20 Most Frequently Used Katakana Symbols

\begin{tabular}{|c|c|c|c|c|}
\hline Ranking & Katakana & Sound & Frequency & $\%$ \\
\hline 1 & - & $/ \mathrm{R} /$ & $2,860,333$ & 10.05 \\
\hline 2 & ン & $/ \mathrm{N} /$ & $2,119,234$ & 7.45 \\
\hline 3 & ル & $/ \mathrm{ru} /$ & $1,448,895$ & 5.09 \\
\hline 4 & ス & /su/ & $1,336,665$ & 4.70 \\
\hline 5 & 卜 & $/$ to/ & $1,188,192$ & 4.17 \\
\hline 6 & 1 & /i/ & 936,791 & 3.29 \\
\hline 7 & ア & $/ \mathrm{a} /$ & 932,222 & 3.28 \\
\hline 8 & ラ & $/ \mathrm{ra} /$ & 905,031 & 3.18 \\
\hline 9 & リ & $/ \mathrm{ri} /$ & 783,483 & 2.75 \\
\hline 10 & ク & $/ \mathrm{ru} /$ & 742,272 & 2.61 \\
\hline 11 & ッ & $/ \mathrm{Q} /$ & 631,694 & 2.22 \\
\hline 12 & 力 & /ka/ & 620,694 & 2.18 \\
\hline 13 & 夕 & $/ \mathrm{ta} /$ & 559,735 & 1.97 \\
\hline 14 & ド & /do/ & 558,191 & 1.96 \\
\hline 15 & 口 & $/ \mathrm{ro} /$ & 528,947 & 1.86 \\
\hline 16 & レ & $/ \mathrm{ri} /$ & 449,324 & 1.58 \\
\hline 17 & ב & /ko/ & 418,221 & 1.47 \\
\hline 18 & $\checkmark$ & $/ \mathrm{ma} /$ & 411,896 & 1.45 \\
\hline 19 & $x$ & $/ \mathrm{me} /$ & 411,418 & 1.45 \\
\hline 20 & プ & $/ \mathrm{bu} /$ & 406,179 & 1.43 \\
\hline
\end{tabular}

Note-The total of katakana frequencies was $28,464,753$. Percentages of katakana frequencies were calculated on the basis of the overall total of $28,464,753$. Shaded rows indicate the three special sounds.

$10.05 \%$ of the total katakana frequency. The second most frequently used katakana was the special sound of the nasal /N/, showing a high frequency of 2,119,234 times, or $7.45 \%$. The special sound of the geminate $/ \mathrm{Q} /$ came in at the 10th position, appearing 631,694 times, or $2.22 \%$. These three special sounds were counted 5,611,261 times, or $19.72 \%$. This result interestingly implies that the special sounds are not exceptional but are, rather, inclined to be commonly used in Japanese alphabetic loanwords.

\section{Syllables Ending With a Nasal $(+\mathbf{N})$}

Phonetically speaking, the Japanese geminate $/ \mathrm{N} /$ has four sounds: [n], [m], [n] and [N].6 Typical examples of these include the [n] in kandai (/kandai/), meaning generous, [m] in danboo (/danboR/), meaning heating, [n] in bunka (/bunka/), meaning culture, and [N] in kekkon (/keQkoN/), meaning marriage ( $[\mathrm{N}]$ is used in the ending of words). However, these four phonetic sounds are all perceived as the single phoneme / $\mathrm{N} /$ by native Japanese speakers. It is also surprising that $/ \mathrm{N} /$ was counted at an extremely high frequency of 35,719,268 times. When Japanese borrowed a variety of Chinese words, the special sound /N/ was heavily adopted to Japanese sounds (for details, see Tamaoka, 2003; Tamaoka, Kirsner, Yanase, Miyaoka, \& Kawakami, 2002). In this sense, /N/ is no longer special with regard to frequency of occurrence.

As is depicted in Figure 1, the single syllables of $\varphi \mathrm{VN}$, CVN, SVN, and CSVN are considered as two morae of $\mathrm{CV}+\mathrm{N}, \mathrm{SV}+\mathrm{N}$, or $\mathrm{CSV}+\mathrm{N}$, since $/ \mathrm{N} /$ is regarded as a single mora. The frequencies of $+\mathrm{N}$ syllables are listed in Table 7. Combinations of $/ \mathrm{k} /+\mathrm{V}+/ \mathrm{N} /$ (i.e., $/ \mathrm{kaN} /$, /kin/, /kun/, /keN/, and /koN/) showed the highest fre- quency at 6,986,514 times, or $19.91 \%$. Among them, /kaN/ was the most frequently repeated syllable, being recorded 3,044,363 times. The second most frequently repeated syllable combination was $/ \mathrm{s} /+\mathrm{V}+/ \mathrm{N} /$ (i.e., /saN/, /sin/, /sun/, /sen/, and/son/). This combination was counted up to $5,998,668$ times, or $17.10 \%$, although /sun/ had a very low count-only 7,513 times. As compared with morae of $\varphi \mathrm{V}$ and $\mathrm{CV}$ with / $/$ combinations, morae with semivowels (i.e., SV and CSV) with /N/ are much less frequently constructed. Among these less frequent morae, the highest was $/ \mathrm{zj} /+\mathrm{V}+/ \mathrm{N} /$, being recorded 275,110 times, or $0.78 \%$. As is shown in Table 7 , the six combinations /pjas/, /pjus/, /hjaN/, /hjus/,/bjas/, and /bjon/ did not appear at all.

\section{Syllables With a Geminate $(+\mathbf{Q}$ and $\mathbf{Q}+)$}

The geminate $/ Q /$ is depicted by a small kana symbol of $\supset$ in hiragana and by $\mathscr{Y}$ in katakana. However, a larger version of the same symbol $つ$ in hiragana or $ツ$ in katakana represents the mora sound /tu/, which has nothing to do with the geminate $/ \mathrm{Q} /$. This sound difference is much easier to recognize when words using the geminate $/ \mathrm{Q} /$ are depicted in the alphabetized script roma-ji. A few examples from the Japanese language are hattatsu (/haQtatu/ in phonemic symbols, meaning development), kippu (/kiepu/, meaning ticket), kakki (/kaQki/, meaning vitality), and masshiro (/maQsiro/, meaning snow-white). As can be seen in roma-ji, any one of the consonants $/ \mathrm{p} /$, $/ \mathrm{t} /, / \mathrm{k} /$, and $/ \mathrm{s} /$ may be geminates. In fact, the geminate $/ \mathrm{Q} /$ represents the duration, approximately the time of one mora, in which one pauses with one's mouth in the shape of the following consonant before pronouncing it (Kawakami, 1977; Komatsu, 1981). In this sense, /Q/ is also referred to as a double consonant.

The geminate $/ \mathrm{Q} /$ does not occur in the onset and the coda of words but is always found in the middle of words. Thus, phoneme and mora frequencies (a syllable with Q) before $/ \mathrm{Q} /$ are shown in Table 8 as $+\mathrm{Q}$, and those after $/ \mathrm{Q} /$ are shown in Table 9 as $\mathrm{Q}+$.

As is shown in Table 8 , the vowel $/ \mathbf{i}$ / in $\varphi \mathrm{V}$ was most frequently positioned before $/ \mathrm{Q} /$. The frequency of $/ \mathrm{iQ} /$ syllable was 545,475 times. In fact, it is easy to find some frequently used expressions, such as /iQpaN/, meaning general, /iQsyo/, meaning together, and /iQkai/, meaning once. The second was the $/ \mathrm{kaQ} /$ syllable, being recorded 454,858 times, often seen in /kaepatu/, meaning active, /kaQsorro/, meaning a runway, and /kaQkazaN/, meaning an active volcano. The third was the $/ \mathrm{keQ} / \mathrm{syllable}$, counted 363,962 times. In contrast, the six syllables of /pjaQ/, /pjuQ/, /pjoQ/, /bjoQ/, /mjuQ/, and /mjoQ/ did not exist in the lexical corpus. Among the $+\mathrm{Q}$ syllables with semivowels, /sjuQ/ was the most frequently recorded at 174,082 times. An example of this is /sjuQseki/, meaning attendance.

On the basis of a common definition (e.g., Kawakami, $1977)$, the actual sound of $/ \mathrm{Q} /$ is not voiced but has a single mora duration of one of the five consonants $[\mathrm{p}],[\mathrm{t}]$, 
Table 7

Frequency Counts of Syllables With Nasal /N/ (+N type)

\begin{tabular}{|c|c|c|c|c|c|c|c|}
\hline & \multicolumn{2}{|c|}{ Total } & \multicolumn{5}{|c|}{ Vowel } \\
\hline & Frequency & $\%$ & $/ \mathrm{a} /$ & /i/ & $/ \mathrm{u} /$ & /e/ & $/ 0 /$ \\
\hline \multicolumn{8}{|c|}{ With Consonants ( $\varphi \mathrm{VN}$ or $\mathrm{CVN})$} \\
\hline$\varphi$ & $3,346,672$ & 9.54 & 576,458 & $1,311,153$ & 253,485 & $1,062,207$ & 143,369 \\
\hline$/ \mathrm{p} /$ & 271,632 & 0.77 & 136,061 & 40,626 & 11,250 & 25,736 & 57,959 \\
\hline$/ \mathrm{t} /$ & $1,502,415$ & 4.28 & 443,181 & 95,099 & 1,185 & 796,614 & 166,336 \\
\hline$/ \mathrm{k} /$ & $6,986,514$ & 19.91 & $3,044,363$ & 975,378 & 52,105 & $2,221,991$ & 692,677 \\
\hline /s/ & $5,998,668$ & 17.10 & $1,764,878$ & $1,915,600$ & 7,513 & $2,106,924$ & 203,753 \\
\hline$/ \mathrm{h} /$ & $2,956,124$ & 8.43 & 886 , & 233,514 & 243,219 & 274,897 & $1,318,015$ \\
\hline$/ \mathrm{b} /$ & $1,287,350$ & 3.67 & 295,866 & 64,245 & 774,031 & 132,820 & 20,388 \\
\hline /d/ & $1,277,236$ & 3.64 & 836,265 & - & - & 369,078 & 71,893 \\
\hline$/ g /$ & $1,860,202$ & 5.30 & 151 & 193,500 & 275,756 & $1,219,511$ & 19,526 \\
\hline $\mid \mathrm{z} /$ & $2,076,189$ & 2 & 101 & 813,732 & 8,560 & 1,109 & 42,248 \\
\hline$/ \mathrm{m} /$ & 13,553 & 6 & 448 & 793,6 & & 92 & 702,339 \\
\hline$/ \mathrm{n} /$ & $3,139,702$ & 8.95 & 341,757 & $1,082,676$ & 737 & $1,693,767$ & 20,765 \\
\hline$/ \mathrm{r} /$ & $1,502,421$ & 4.28 & 293,375 & 254,448 & 5,465 & 642,304 & 306,829 \\
\hline \multicolumn{8}{|c|}{ With Semivowels (SVN) } \\
\hline /W/ & 91,975 & 0.26 & 91,975 & - & - & - & - \\
\hline$/ \mathbf{j} /$ & 92,974 & 0.27 & 5,707 & - & 809 & - & 86,458 \\
\hline \multicolumn{8}{|c|}{ With Contracted Sounds (CSVN) } \\
\hline$/ \mathrm{pj} /$ & 203 & 0.00 & 0 & - & 0 & - & 203 \\
\hline$/ \mathrm{tj} /$ & 45,357 & 0.13 & 36 & - & 209 & - & 412 \\
\hline$/ \mathrm{kj} /$ & 20,125 & 0.06 & 20,089 & - & 2 & - & 34 \\
\hline$/ \mathrm{s} \mathbf{j} /$ & 129,765 & 0.37 & 14,514 & - & 60,730 & - & 54,521 \\
\hline$/ \mathrm{hj} /$ & 244 & 0.00 & 0 & - & 0 & - & 244 \\
\hline /bj/ & 2 & 0.00 & 0 & - & 2 & - & 0 \\
\hline$/ \mathrm{gj} /$ & 1,471 & 0.00 & 1,423 & - & 45 & - & \\
\hline$/ \mathrm{zj} /$ & 275,110 & 0.78 & 15,994 & - & 249,357 & - & 9,759 \\
\hline$/ \mathrm{mj} /$ & 6,005 & 0.02 & 4,277 & - & 1,722 & - & 6 \\
\hline$/ \mathrm{nj} /$ & 238 & 0.00 & 30 & - & 131 & - & 77 \\
\hline$/ \mathrm{rj} /$ & 201 & 0.00 & 192 & - & 7 & - & 2 \\
\hline Total & $35,082,145$ & 100.00 & $9,519,432$ & $7,773,646$ & $1,946,684$ & $11,924,770$ & $3,917,613$ \\
\hline
\end{tabular}

Note-There are more combinations with $/ \mathrm{N} /$. Thus, the total frequency of a single $/ \mathrm{N} /$ $(35,719,268)$ is higher than the total of $35,082,145$.

$[\mathrm{k}]$, [s], and [J] placed after $/ \mathrm{Q} /$. Table 9 shows the frequencies of the four phonemes $/ \mathrm{p} /, / \mathrm{t} /, / \mathrm{k} /$, and $/ \mathrm{s} /([\mathrm{J}]$ is included in $/ \mathrm{s} /$ ) placed after $/ \mathrm{Q} /$. These combinations are depicted by shadow in Table 9 , with frequencies equaling $4,683,681$ times, or $98.87 \%$ of the total combinations. $/ \mathrm{Qka} /$ was the highest frequency, having a rate of 624,174 times. /Qte/ was the second at 507,742 times, and /Qto/ was the third at 421,717 times.

There were 53,656 cases $(1.13 \%$ of $Q+$ combinations) of deviations from the traditional definition of $/ \mathrm{p} /$, $/ \mathrm{t} /, / \mathrm{k} /$, and $/ \mathrm{s} /$ after $/ \mathrm{Q} /$. Among them, $/ \mathrm{d} /, / \mathrm{h} /, / \mathrm{g} /$, and $/ \mathrm{z} /$ after $/ \mathrm{Q} /$ were counted 52,969 times. Among these consonants, $/ \mathrm{d} /$ was the most frequently placed after $/ \mathrm{Q} /$, being counted 22,872 times, or $0.48 \%$. A phonemic combination of /Qdo/ showed the highest frequency at 22,379 times. These new combinations with $/ \mathrm{Q} /$ suggest that Japanese sounds have gradually diversified by adopting various alphabetic loanwords, especially from English.

\section{Index of Bi-Mora Frequency Counts}

An index for how often two moraic units are combined among Japanese words is called a bi-mora frequency of occurrence. Since all Japanese words can be presented in kana, bi-mora frequencies are calculated on the basis of two kana combinations. For example, the combination of the morae /hi/ (ヒ) and /to/ (ト) appears as a word unit 229,773 times, whereas the same combination appears 615,869 times as a part of words, including its combination as a single word /hito/, meaning human. The index of bimora frequencies of occurrence regarding 4,624 two-kana (mora) combinations with a total of 298,339,034 times are provided as an Excel file in the order of high to low, including 224 bi-mora combinations of 0 frequency counts.

The top 20 bi-mora frequency counts are reported in Table 10. There were 10 bi-mora combinations of CV plus $\mathrm{V}$ in the top 20. Furthermore, 5 bi-mora combinations were $\mathrm{CV}$ plus the special sound $/ \mathrm{N} /$ among the top 20. Only 3 bi-mora combinations were $\mathrm{CV}$ plus $\mathrm{CV}$ in the top 20 (i.e., $/ \mathrm{su} /+/ \mathrm{ru} /, / \mathrm{re} /+/ \mathrm{ru} /$, and $/ \mathrm{ko} /+/ \mathrm{ku} /$ ). In the frequency ranking, the combination of $/ \mathrm{ka} /$ and $/ \mathrm{i} /$ was the highest, being counted 4,269,940 times. Second was $/ \mathrm{te} /$ and $/ \mathrm{i} /$ at 3,851,691 times. Third was $/ \mathrm{ko} /$ and $/ \mathrm{u} /$, occurring 3,669,655 times; fourth was /se/ and /i/, being counted 3,661,544 times. These top 4 bi-mora combinations are all $\mathrm{CV}$ plus $\mathrm{V}$ combinations. The combination of /ka/ plus /N/ was fifth, appearing 3,044,363 times. 
Table 8

Frequency Counts of Syllables With Geminate /Q/ (+Q)

\begin{tabular}{|c|c|c|c|c|c|c|c|}
\hline & \multicolumn{2}{|c|}{ Total } & \multicolumn{5}{|c|}{ Vowel } \\
\hline & Frequency & $\%$ & $/ \mathrm{a} /$ & /i/ & $/ \mathrm{u} /$ & /e/ & $/ 0 /$ \\
\hline \multicolumn{8}{|c|}{ With Consonants ( $\varphi$ VQ or CVQ) } \\
\hline$\varphi$ & 693,336 & 13.79 & 67,060 & 545,475 & 52,435 & 19,642 & 8,724 \\
\hline$/ \mathrm{p} /$ & 38,604 & 0.77 & 8,378 & 16,216 & 745 & 8,473 & 4,792 \\
\hline$/ \mathrm{t} /$ & 316,090 & 6.29 & 98,351 & 14,586 & 8,153 & 81,718 & 113,282 \\
\hline$/ \mathrm{k} /$ & $1,088,220$ & 21.65 & 454,858 & 50,820 & 9,056 & 363,962 & 209,524 \\
\hline /s/ & 415,492 & 8.26 & 90,730 & 102,525 & 9,479 & 185,670 & 27,088 \\
\hline$/ \mathrm{h} /$ & 531,613 & 10.57 & 344,826 & 48,097 & 50,784 & 3,255 & 84,651 \\
\hline$/ \mathrm{b} /$ & 168,535 & 3.35 & 42,753 & 16,511 & 75,964 & 23,594 & 9,713 \\
\hline$/ \mathrm{d} /$ & 104,491 & 2.08 & 90,999 & - & - & 3,453 & 10,039 \\
\hline$/ g /$ & 206,361 & 4.10 & 181,921 & 5,717 & 3,128 & 12,728 & 2,867 \\
\hline $\mid \mathrm{z} /$ & 330,426 & 6.57 & 24,293 & 272,866 & 10,640 & 19,338 & 3,289 \\
\hline$/ \mathrm{m} /$ & 240,152 & 4.78 & 61,064 & 54,495 & 1,802 & 14,237 & 108,554 \\
\hline$/ \mathrm{n} /$ & 237,301 & 4.72 & 21,264 & 162,392 & 34 & 48,631 & 4,980 \\
\hline$/ \mathrm{r} /$ & 201,010 & 4.00 & 38,113 & 78,517 & 2,250 & 35,694 & 46,436 \\
\hline \multicolumn{8}{|c|}{ With Semivowels (SVQ) } \\
\hline$/ \mathrm{w} /$ & 8,899 & 0.18 & 8,899 & - & - & - & - \\
\hline$/ \mathbf{j} /$ & 131,420 & 2.61 & 36,591 & - & 7,159 & - & 87,670 \\
\hline \multicolumn{8}{|c|}{ With Contracted Sounds (CSVQ) } \\
\hline$/ \mathrm{pj} /$ & 0 & 0.00 & 0 & - & 0 & - & 0 \\
\hline$/ \mathrm{tj} /$ & 41,906 & 0.83 & 8,745 & - & 3 & - & 33,158 \\
\hline$/ \mathrm{kj} /$ & 12,754 & 0.25 & 12,324 & - & 40 & - & 390 \\
\hline$/ \mathrm{s} \mathbf{j} /$ & 210,130 & 4.18 & 15,613 & - & 174,082 & - & 20,435 \\
\hline$/ \mathrm{hj} /$ & 12,700 & 0.25 & 11,673 & - & 50 & - & 977 \\
\hline$/ \mathrm{b} \mathbf{j} /$ & 390 & 0.01 & 116 & - & 274 & - & 0 \\
\hline$/ \mathrm{gj} /$ & 4,108 & 0.08 & 3,839 & - & 92 & - & 177 \\
\hline$/ \mathrm{zj} /$ & 27,113 & 0.54 & 5,462 & - & 21,289 & - & 362 \\
\hline$/ \mathrm{mj} /$ & 8 & 0.00 & 8 & - & 0 & - & 0 \\
\hline$/ \mathrm{nj} /$ & 119 & 0.00 & 86 & - & 13 & - & 20 \\
\hline$/ \mathrm{rj} /$ & 6,256 & 0.12 & 118 & - & 4,832 & - & 1,306 \\
\hline Total & $5,027,434$ & 100.00 & $1,628,084$ & $1,368,217$ & 432,304 & 820,395 & 778,434 \\
\hline
\end{tabular}

The bi-mora frequencies are also arranged in $100 \times$ 102 bi-mora matrix providing bi-mora frequency counts not only for $\varphi \mathrm{V}$ and $\mathrm{CV}$ combinations, but also for the contracted sounds CSV and SV and two special sounds $/ \mathrm{N} /$ and $/ \mathrm{Q} /$. A $68 \times 68$ matrix excluding the contracted and special sounds is also provided, since the simple moraic combinations of $\varphi \mathrm{V}$ and $\mathrm{CV}$ are often preferred for constructing stimuli in psychological experiments in phonology. Although it is well known that word frequency affects phonological processing (e.g., Fushimi, Ijuin, Patterson, \& Tatsumi, 1999; Hino \& Lupker, 1998; Taft, 1979, 1991), it has not yet been clearly indicated whether or not bi-mora frequency of occurrence affects Japanese phonological processing independently from word frequency. Thus, the bi-mora frequencies of occurrence are also provided by the Web-accessible database.

\section{Web Sites of the Frequency Indexes of Phonemes, Morae, Syllables, and Bi-Morae for Downloading}

Four separate zip files containing Excel files may be downloaded from the Psychonomic Society Web archive, http://www.psychonomic.org/archive/. The database is stored as (1) bi-mora_frequency_index.zip (58.15K), providing the bi-mora frequency index, (2) bi-mora matrix_100.zip (24.77K), providing the $100 \times 102$ bimora matrix Excel table, (3) bi-mora_matrix_68.zip $(17.74 \mathrm{~K})$, providing the $68 \times 68$ bi-mora matrix Excel table, and (4) frequency_index.zip (11.78K), containing the frequency indexes of phonemes, morae, and syllables. The data above may also be accessed from the homepage of Katsuo Tamaoka on the Web site of Hiroshima University, Japan, http://home.hiroshima-u.ac.jp/ktamaoka/ (Excel, zip, and PDF files).

\section{Summary}

In order to provide phonological familiarity, the present study has reported frequency counts for units of Japanese phonemes, morae, and syllables, using the word printed frequency index constructed from 1985 to 1998 editions of the Asahi newspaper (originally prepared by Amano \& Kondo, 2000).

Frequency counts provide a clear picture of trends in Japanese phonology. The type and token frequency of 101 moraic units represented by kana indicated a high correlation $(r=.908)$, suggesting no difference between type and token frequency counts of kana units. Among the five vowels appearing as a single unit $(\varphi \mathrm{V}), / \mathrm{i} /$ was the most frequent, whereas /e/ was the least frequent. Once all possible combinations with the five vowels 
Table 9

Frequency Counts of Geminate $/ \mathrm{Q} /$ and Mora Combinations $(\mathrm{Q}+)$

\begin{tabular}{|c|c|c|c|c|c|c|c|}
\hline & \multicolumn{2}{|c|}{ Total } & \multicolumn{5}{|c|}{ Vowel } \\
\hline & Frequency & $\%$ & $/ \mathrm{a} /$ & /i/ & $/ \mathrm{u} /$ & /e/ & $/ 0 /$ \\
\hline \multicolumn{8}{|c|}{ With Consonants $(\mathrm{Q}+\varphi \mathrm{V}$ or $\mathrm{Q}+\mathrm{CV})$} \\
\hline$\varphi$ & 0 & 0.00 & 0 & 0 & 0 & 0 & 0 \\
\hline$/ \mathrm{p} /$ & 549,181 & 11.59 & 216,237 & 24,649 & 95,274 & 26,377 & 186,644 \\
\hline /t/ & $1,320,303$ & 27.87 & 275,356 & 93,811 & 21,677 & 507,742 & 421,717 \\
\hline$/ \mathrm{k} /$ & $1,524,225$ & 32.17 & 624,174 & 150,228 & 208,466 & 135,416 & 405,941 \\
\hline /s/ & 724,177 & 15.29 & 120,915 & 237,532 & 59,722 & 206,956 & 99,052 \\
\hline$/ \mathrm{h} /$ & 12,538 & 0.26 & 1,365 & 83 & 10,461 & 26 & 603 \\
\hline$/ \mathrm{b} /$ & 500 & 0.01 & 91 & 0 & 398 & 1 & 10 \\
\hline /d/ & 22,872 & 0.48 & 492 & - & - & 1 & 22,379 \\
\hline$/ g /$ & 10,190 & 0.22 & 142 & 38 & 9,988 & 0 & 22 \\
\hline$|\mathbf{z}|$ & 7,369 & 0.16 & 1 & 5,514 & 1,854 & 0 & 0 \\
\hline$/ \mathrm{m} /$ & 0 & 0.00 & 0 & 0 & 0 & 0 & 0 \\
\hline$/ \mathrm{n} /$ & 0 & 0.00 & 0 & 0 & 0 & 0 & 0 \\
\hline$/ \mathbf{r} /$ & 37 & 0.00 & 31 & 1 & 0 & 0 & 5 \\
\hline \multicolumn{8}{|c|}{ With Semivowels $(\mathrm{Q}+\mathrm{SV})$} \\
\hline$/ \mathrm{w} /$ & 0 & 0.00 & 0 & - & - & - & - \\
\hline$/ \mathrm{j} /$ & 0 & 0.00 & 0 & - & 0 & - & 0 \\
\hline \multicolumn{8}{|c|}{ With Contracted Sounds $(\mathrm{Q}+\mathrm{CSV})$} \\
\hline$/ \mathrm{pj} /$ & 120,286 & 2.54 & 34 & - & 0 & - & 120,252 \\
\hline$/ \mathrm{tj} /$ & 81,362 & 1.72 & 27,878 & - & 26,742 & - & 26,742 \\
\hline$/ \mathrm{kj} /$ & 143,512 & 3.03 & 4,150 & - & 27,303 & - & 112,059 \\
\hline$/ \mathrm{sj} /$ & 220,635 & 4.66 & 31,402 & - & 75,847 & - & 113,386 \\
\hline /hj/ & 0 & 0.00 & 0 & - & 0 & - & 0 \\
\hline /bj/ & 0 & 0.00 & 0 & - & 0 & - & 0 \\
\hline$/ g \mathrm{j} /$ & 3 & 0.00 & 0 & - & 3 & - & 0 \\
\hline$/ \mathrm{zj} /$ & 147 & 0.00 & 62 & - & 0 & - & 85 \\
\hline$/ \mathrm{mj} /$ & 0 & 0.00 & 0 & - & 0 & - & 0 \\
\hline$/ \mathrm{nj} /$ & 0 & 0.00 & 0 & - & 0 & - & 0 \\
\hline /rj/ & 0 & 0.00 & 0 & - & 0 & - & 0 \\
\hline Total & $4,737,337$ & 100.00 & $1,302,330$ & 511,856 & 537,735 & 876,519 & $1,508,897$ \\
\hline
\end{tabular}

were included in frequency counts, this trend changed: $/ \mathrm{u} /$ became the most and $/ \mathrm{e} /$ remained the least frequent. Among the 12 consonants, $/ \mathrm{k} /$ showed the highest counts, whereas $/ \mathrm{p} /$ showed the lowest. The present study has also reported contracted sounds. The $/ \mathrm{sj} /$ with vowels appeared most frequently. Among the CSV moraic units, /sjo/ appeared most frequently, whereas /pja/ was the least, being counted only 95 times. The Japanese government provided guidelines of katakana usages for alphabetic loanwords, by officially recognizing an additional 33 moraic expressions. Among these, $/ \mathrm{ti} /$ appeared most frequently. The consonant /f/ for $/ \mathrm{fa} /, / \mathrm{fi} /, / \mathrm{fe} /$, and /fo/ is already accepted in Japanese sounds, appearing at a relatively high frequency of 60,484 times.

The present study has provided frequency counts for special sounds. Among the five long vowels, /ar/ showed the highest frequency, whereas /uR/ was the lowest frequency. It was also interesting to find that the long vowel $/ \mathrm{R} /$ (represented by a horizontal line - in katakana) appeared the most frequently in katakana-presented loanwords. The study also showed that the special sound $/ \mathrm{N} /$ appeared very often, being counted 35,719,268 times. Among various syllabic combinations including $/ \mathrm{N} /$, the combination of $/ \mathrm{k} /+\mathrm{V}+/ \mathrm{N} /$ showed the highest frequency counts. At 7,858,931 times, the special sound /Q/ was also found to appear very frequently. The frequency of
/iQ/ was the highest among the combinations with $/ \mathrm{Q} /$. As such, frequency counts tell us that the three well-known special sounds are actually not special in terms of occurrence in a Japanese newspaper.

Table 10

The Top 20 Bi-Mora Frequency Counts

\begin{tabular}{rllll}
\hline No. & Kana & Phonemes & Frequency & $\%$ \\
\hline 1 & カイ & $/ \mathrm{ka} /+/ \mathrm{i} /$ & $4,269,940$ & 1.43 \\
2 & テイ & $/ \mathrm{te} /+/ \mathrm{i} /$ & $3,851,691$ & 1.29 \\
3 & コウ & $/ \mathrm{ko} /+/ \mathrm{u} /$ & $3,669,655$ & 1.23 \\
4 & セイ & $/ \mathrm{se} /+/ \mathrm{i} /$ & $3,661,544$ & 1.23 \\
5 & カン & $/ \mathrm{ka} /+/ \mathrm{N} /$ & $3,044,363$ & 1.02 \\
6 & イル & $/ \mathrm{i} /+/ \mathrm{ru} /$ & $3,016,280$ & 1.01 \\
7 & スル & $/ \mathrm{su} /+/ \mathrm{ru} /$ & $2,935,841$ & 0.98 \\
8 & トウ & $/ \mathrm{to} /+/ \mathrm{u} /$ & $2,708,538$ & 0.91 \\
9 & ナイ & $/ \mathrm{na} /+/ \mathrm{i} /$ & $2,653,620$ & 0.89 \\
10 & レル & $/ \mathrm{re} /+/ \mathrm{ru} /$ & $2,643,258$ & 0.89 \\
11 & タイ & $/ \mathrm{ta} /+/ \mathrm{i} /$ & $2,632,623$ & 0.88 \\
12 & ウシ & $/ \mathrm{u} /+/ \mathrm{si} /$ & $2,282,422$ & 0.77 \\
13 & ケン & $/ \mathrm{ke} /+/ \mathrm{N} /$ & $2,221,991$ & 0.74 \\
14 & ダイ & $/ \mathrm{da} /+/ \mathrm{i} /$ & $2,120,498$ & 0.71 \\
15 & セン & $/ \mathrm{se} /+/ \mathrm{N} /$ & $2,106,924$ & 0.71 \\
16 & ヨウ & $/ \mathrm{jo} /+/ \mathrm{u} /$ & $1,999,208$ & 0.67 \\
17 & ドウ & $/ \mathrm{do} /+/ \mathrm{u} /$ & $1,930,217$ & 0.65 \\
18 & シン & $/ \mathrm{si} /+/ \mathrm{N} /$ & $1,915,600$ & 0.64 \\
19 & コク & $/ \mathrm{ko} /+/ \mathrm{ku} /$ & $1,851,379$ & 0.62 \\
20 & サン & $/ \mathrm{sa} /+/ \mathrm{N} /$ & $1,764,878$ & 0.59 \\
\hline
\end{tabular}

Note-The total of bi-mora token frequencies is $298,339,034$. 


\section{REFERENCES}

Amano, N., \& Kondo, K. (2000). Nihongo-no goi tokusei [Lexical properties of Japanese]. Tokyo: Sanseido.

Amanuma, Y., Otsubo, K., \& Mizutani, O. (1996). Nihongo onseigaku [Japanese phonetics]. Tokyo: Kuroshio Shuppan.

BESNER, D., \& HiLdEBRANDT, N. (1987). Orthographic and phonological codes in the oral reading of Japanese kana. Journal of Experimental Psychology: Learning, Memory, \& Cognition, 13, 335-343.

Cutler, A., \& OTAKe, T. (1994). Mora or phoneme? Further evidence for language-specific listening. Journal of Memory \& Language, 33, 824-844.

ENDO, O. (1989). Gairaigo-no hyooki [A script for alphabetic loanwords]. In Y. Takebe (Ed.), Kooza nihongo to nihongo kyooiku, dai8-kan: Nihongo no moji hyooki (jo) [Japanese language and Japanese language education series, Vol. 8: Script and orthography of the Japanese Language (part 1)] (pp. 213-246). Tokyo: Meiji Shoin.

Fushimi, T., IJuin, M., Patterson, K., \& Tatsumi, I. F. (1999). Consistency, frequency, and lexicality effects in naming Japanese kanji. Journal of Experimental Psychology: Human Perception \& Performance, 25, 382-407.

GOVERNMENT OF JAPAN (1991). Gairaigo-no hyooki [Describing foreign words]. Cabinet Announcement No. 2, June 28, 1991.

HaN, M. S. (1992). The timing control of geminate and single stop consonants in Japanese: A challenge for nonnative speakers. Phonetica, 49, 102-127.

Haraguchi, S. (1996). Syllable, mora and accent. In T. Otake \& A. Cutler (Eds.), Phonological structure and language processing: Cross-linguistic studies (pp. 45-75). New York: Mouton de Gruyter.

HatToRI, S. (1955). On'inron (1) [Phonology (1)]. Kokugo-gaku [A study of the Japanese language], 22, 279-301.

HattoRi, S. (1956). On'inron (3) [Phonology (3)]. Kokugo-gaku [A study of the Japanese language], 26, 302-322.

HattoRI, S. (1958). Nihongo-no On'in [Japanese Phonology]. Sekai dai hyakka jiten, 22 [World Encyclopedia 22], 360-364.

HINO, Y., \& LUPKER, S. L. (1998). Effects of word frequency for Japanese kana and kanji word naming and lexical decision: Can the dual-route model save the lexical-selection account? Journal of Experimental Psychology: Human Perception \& Performance, 24, 1431-1453.

IsHIHARA, J. (1995). Nihongo-ni okeru masatsuon, haretsuon, hasatsuonno bunpu pataan [A distributed pattern of Japanese fricatives, plosives and affricates]. Nagoya Working Paper in Linguistics, 11, 133-157.

IsHIHARA, J. (1997). Nihongo on'in taikei-ni okeru yoo'on no ityizukeni kansuru koosatu [A study of the locus of contracted sounds in Japanese phonology]. Nagoya Working Paper in Linguistics, 13, 71-90.

Jouo, H. (1977). Gendai nihongo-no on'in [Phonology of modern Japanese]. In S. Oono \& T. Shibata (Eds.), Iwanami Kooza Nihongo: Vol. 5. On'in [Iwanami Lecture Series on Japanese: Vol. 5. Phonology] (pp. 107-145). Tokyo: Iwanami Shoten.

KAWAKAMI, S. (1977). Nihongo onsei gaisetu [An introduction to Japanese phonetics]. Tokyo: Baihusha.

KolzumI, T. (1989). Onsei to on'in [Phonetics and phonology]. In M. Sugihuji (Ed.), Kooza nihongo to nihongo kyooiku: Vol. 2. Nihongono onsei on 'in [Japanese language and Japanese education series: Vol. 2. Japanese phonetics and phonology] (pp. 1-20). Tokyo: Meiji Shoin.

KoIzumi, T. (1990). Watasi-no gojuu'onzu kan [Ideas regarding the fifty-sound table]. Nihongogaku [Study on the Japanese Language] 9, 4-9.

KoKuritsu KoKugo Kenkyujo [the National Institute for Japanese Language] (1983). Kokuritsu kokugo kenkyuujo houkoku 75: Gendai hyooki no yure [Report 75 of the National Japanese Language Research Institute: Tremble of modern script]. Tokyo: Author.

Komatsu, H. (1981). Nihongo-no on 'in [Japanese phonology]. Tokyo: Chuo Koronsha.

Kubozono, H. (1989). The mora and syllable structure in Japanese: Evidence from speech errors. Language \& Speech, 32, 249-278.

Kubozono, H. (1995). Perceptual evidence for the mora in Japanese. In B. Connell \& A. Arvaniti (Eds.), Phonology and phonetic evidence:
Papers in laboratory phonology IV (pp. 141-156). Cambridge: Cambridge University Press.

Kubozono, H. (1999). Nihongo-no onsei [Japanese sounds]. Tokyo: Iwanami Shoten.

Kubozono, H. (2002). Shingo-wa kooshite tsukurareru [How new words are made]. Tokyo: Iwanami Shoten.

Kubozono, H., \& OTa, S. (1998). On'in koozoo to akusento [Phonological structure and accents]. Tokyo: Kenkyusha Shuppan.

MatSUZAKI, H. (1993). Gairaigo to gendai nihongo on'in taikei [Loanwords and the modern Japanese phonological system]. Tsukuba Daigaku Kokugo Kokubungaku Kai [Society of Tsukuba University Japanese Language and Literature], 18, 22-30.

MatsuZAKI, H. (1994). Wago, kango, gairaigo-no gokei to tokusyu haku-no onhairetu joo-no seiyaku [Frequencies of the Japanese special sounds in the lexical categories of wago, kango and gairaigo] Journal of the Department of Japanese, Tohoku University, 4, 75-86.

Numoto, K. (1987). Nihon kanzion-no kenkyuu [A study of Japanese kanji sounds]. Tokyo: Tokyodo Shuppan.

OKUMURA, M. (1977). On'in no hensen (2) [Transition of the Japanese phonology (2)]. In S. Ohno \& T. Shibata (Eds.), Nihongo 5: On'in [Japanese 5: Phonology] (pp. 221-252). Tokyo: Iwanami Shoten.

Otake, T., Hatano, G., Cutler, A., \& Mehler, J. (1993). Mora or syllable? Speech segmentation in Japanese. Journal of Memory \& Language, 32, 358-378.

Otake, T., Hatano, G., \& Yoneyama, K. (1996). Speech segmentation by Japanese listeners. In T. Otake \& A. Cutler (Eds.), Phonological structure and language processing: Cross-linguistic studies (pp. 183-201). Berlin: Mouton de Gruyter.

SugrTo, M. (1989). Haku ka onsetsu ka [Mora or syllable?]. In M. Sugito (Ed.), Nihongo no onsei on 'in [Japanese phonetics and phonology] (pp. 154-177). Tokyo: Meiji Shoin

TAFT, M. (1979). Recognition of affixed words and the word frequency effect. Memory \& Cognition, 7, 263-272.

TAFT, M. (1991). Reading and the mental lexicon. Hillsdale, NJ: Erlbaum.

TАмАока, K. (2003). Where do statistically-derived indicators and human strategies meet when identifying on- and kun-readings of Japanese kanji? Cognitive Studies, 10, 1-28.

Tamaoka, K., Kirsner, K., Yanase, Y., Miyaoka, Y., \& KawaKami, M. (2002). A Web-accessible database of characteristics of the 1,945 basic Japanese kanji. Behavior Research Methods, Instruments, \& Computers, 34, 260-275.

TAMAOKA, K., \& MiYAOKA, Y. (2003). The cognitive processing of Japanese loanwords in katakana. Japanese Psychological Research, 45, 69-79.

TAmaOKa, K., \& Murata, T. (2001). OCP effects on Japanese phonological processing. Phonological Studies, 4, 119-126.

Tamaoka, K., \& Terao, Y. (2004). Mora or syllable: Which unit do Japanese use in naming visually-presented stimuli? Applied Psycholinguistics, 25, 1-27.

Terao, Y. (2002). Iiayamari wa dooshite okoru ka? [How do speech errors occur?]. Tokyo: Iwanami Shoten.

VANCE, T. J. (1987). An introduction to Japanese phonology. Albany, NY: State University of New York Press.

Warner, N., \& AraI, T. (2001). Japanese mora-timing: A review. Phonetica, 58, 1-25.

\section{NOTES}

1. In this article, including references, an alphabetic description of Japanese names follows the commonly used Hepburn style. Since the Hepburn style does not distinguish between long and short vowels (e.g. the proper name of Kondo is pronounced / koNdoR/ with a long vowel at the end), this article uses the spelling of Kondo, not Kondoo. However, to represent precise sounds, Japanese titles of research papers that include long vowels are shown by repeating the same vowels twice, such as oo.

2 . The phonemic symbol $/ \mathrm{j} /$ is used for semivowels in contracted sounds, such as $/ \mathrm{kja} /$ (キャ), $/ \mathrm{pja} /($ ピヤ), and /bjo/ (ビヨ). Instead of $/ \mathrm{j} /$, some phonologists use $/ \mathrm{y} /$ for the same sound. The capital $\mathrm{J}$ or $/ \mathrm{J} /$ 
refers to the second vowel in dual-vowel combinations. For example, since / $\mathrm{kai} /$ contains dual vowels of /ai/, it is described as CVJ (consonant + vowel+vowel). As such, a small letter $/ \mathrm{j} /$ and a capital $\mathrm{J}$ refer to different phonological elements.

3. The phonemic symbol $/ \mathrm{j} /$ usually refers to contracted moraic sounds. However, the expression $/ \mathrm{j} /$ is occasionally used for noncontracted sounds. Although Hattori (1955) used /ci/ for the same sound, Matsuzaki (1993) used /j/ for /cji/ (チ). In this article, we adapted the system of phonemic expressions provided by Matsuzaki.

4. There is no clear outline to express all Japanese sounds perfectly using phonemic symbols. In order to avoid overlaps of phonemic symbols as much as possible, we set a standard to use /cji/ for $千$ (allophone of the /t/-line mora sounds), /ti/ for ティ, and /ci/ for ツィ. Hattori (1955) described the /t/-line morae as /ta/, /ci/,/cu/,/te/, and /to/. However, he did not discuss about a newer mora, ティ. After this mora became popular, Matsuzaki (1993) adapted a different way, using the phonemic symbols /ci/ for ツィ,/ti/ for ティ, and /cji/ for チ. The phonemic expressions in the present study are basically adapted from Matsuzaki (1993). The phonemic expression/c/ is also used for/ca/ for ツア,/ce/ for ツエ, and /co/ for ツォ (see Appendix B). The actual debate on this issue is much more complicated (see the detailed discussions in Hattori, 1955, 1956, 1958; Ishihara, 1997; Matsuzaki, 1993, 1994). Since this issue is beyond the scope and purpose of this article, this question is only briefly mentioned.

5. The phoneme /f/ refers to an unvoiced labio-dental fricative or an unvoiced bilabial fricative.

6. The brackets, [ ], refer to phonetic symbols, whereas backslashes, $/ /$, refer to phonemic symbols.

\section{ARCHIVED MATERIALS}

The following materials associated with this article may be accessed through the Psychonomic Society's Norms, Stimuli, and Data archive, http://www.psychonomic.org/archive/.

To access these files or links, search the archive for this article using the journal (Behavior Research Methods, Instruments, \& Computers), the first author's name (Tamaoka), and the publication year (2004).

FILE: Tamaoka-BRMIC-2004a.zip.

DESCRIPTION: Four zip files with frequency indexes and matrixes related to the Tamaoka (2004) article. 
APPENDIX A

Frequency Counts of the 100 Basic Morae and Three Special Sounds

\begin{tabular}{|c|c|c|c|c|c|c|c|}
\hline & $\begin{array}{c}\text { Phonemic } \\
\text { Combination }\end{array}$ & Mora & Cons/Semi & Vowel & Katakana & Token Frequency & Type Frequenc \\
\hline \multicolumn{8}{|c|}{ Vowels /a/, /e/, /i/, /o/, and /u/ } \\
\hline 1 & $\varphi \mathrm{V}$ & a & $\varphi$ & a & ア & $6,149,909$ & 18,898 \\
\hline 2 & $\varphi \mathrm{V}$ & $\mathrm{i}$ & $\varphi$ & $\mathrm{i}$ & 1 & $43,985,426$ & 67,643 \\
\hline 3 & $\varphi \mathrm{V}$ & $\mathrm{u}$ & $\varphi$ & $\mathrm{u}$ & ウ & $39,052,254$ & 84,624 \\
\hline 4 & $\varphi \mathrm{V}$ & $\mathrm{e}$ & $\varphi$ & $\mathrm{e}$ & $I$ & $4,767,153$ & 14,103 \\
\hline 5 & $\varphi \mathrm{V}$ & o & $\varphi$ & o & オ & $14,053,377$ & 22,195 \\
\hline \multicolumn{8}{|c|}{$/ \mathrm{p} /, / \mathrm{t} /$, and $/ \mathrm{k} /$ (Voiceless, Stop) } \\
\hline 6 & $\mathrm{CV}$ & pa & $\mathrm{p}$ & a & パ & 984,460 & 2,937 \\
\hline 7 & $\mathrm{CV}$ & pi & $\mathrm{p}$ & $\mathrm{i}$ & $ヒ^{\circ}$ & 192,847 & 1,343 \\
\hline 8 & $\mathrm{CV}$ & $\mathrm{pu}$ & $\mathrm{p}$ & $\mathrm{u}$ & プ & 445,557 & 3,480 \\
\hline 9 & $\mathrm{CV}$ & pe & $\mathrm{p}$ & $\mathrm{e}$ & ヘำ & 182,551 & 1,165 \\
\hline 10 & $\mathrm{CV}$ & po & $\mathrm{p}$ & o & ポ & 507,561 & 2,183 \\
\hline 11 & $\mathrm{CV}$ & ta & $\mathrm{t}$ & $\mathrm{a}$ & 夕 & $16,442,465$ & 27,384 \\
\hline 12 & $\mathrm{CV}$ & cji & $\mathrm{cj}$ & $\mathrm{i}$ & 千 & $5,808,199$ & 19,482 \\
\hline 13 & $\mathrm{CV}$ & tu & $\mathrm{t}$ & $\mathrm{u}$ & ッ & $9,612,206$ & 22,853 \\
\hline 14 & $\mathrm{CV}$ & te & $\mathrm{t}$ & $\mathrm{e}$ & テ & $11,037,767$ & 12,822 \\
\hline 15 & $\mathrm{CV}$ & to & $\mathrm{t}$ & o & ト & $17,102,180$ & 27,131 \\
\hline 16 & $\mathrm{CV}$ & $\mathrm{ka}$ & $\mathrm{k}$ & $\mathrm{a}$ & 力 & $20,530,065$ & 43,982 \\
\hline 17 & $\mathrm{CV}$ & $\mathrm{ki}$ & $\mathrm{k}$ & $\mathrm{i}$ & $\neq$ & $9,926,212$ & 31,183 \\
\hline 18 & $\mathrm{CV}$ & $\mathrm{ku}$ & $\mathrm{k}$ & $\mathrm{u}$ & ク & $17,211,261$ & 38,359 \\
\hline 19 & $\mathrm{CV}$ & $\mathrm{ke}$ & $\mathrm{k}$ & $\mathrm{e}$ & ケ & $6,823,149$ & 14,873 \\
\hline 20 & $\mathrm{CV}$ & ko & $\mathrm{k}$ & o & $\exists$ & $12,154,255$ & 27,551 \\
\hline \multicolumn{8}{|c|}{$/ \mathrm{s} /$ and $/ \mathrm{h} /($ Voiceless, Fricative $)$} \\
\hline 21 & $\mathrm{CV}$ & $\mathrm{sa}$ & $\mathrm{s}$ & $\mathrm{a}$ & サ & $7,932,086$ & 22,624 \\
\hline 22 & $\mathrm{CV}$ & si & $\mathrm{s}$ & $\mathrm{i}$ & シ & $16,518,016$ & 40,585 \\
\hline 23 & $\mathrm{CV}$ & su & $\mathrm{s}$ & $\mathrm{u}$ & ス & $9,271,734$ & 22,763 \\
\hline 24 & $\mathrm{CV}$ & se & $\mathrm{s}$ & $\mathrm{e}$ & セ & $8,127,590$ & 16,836 \\
\hline 25 & $\mathrm{CV}$ & so & $\mathrm{s}$ & o & ソ & $4,303,939$ & 8,857 \\
\hline 26 & $\mathrm{CV}$ & ha & $\mathrm{h}$ & $\mathrm{a}$ & 八 & $12,594,714$ & 12,919 \\
\hline 27 & $\mathrm{CV}$ & hi & $\mathrm{h}$ & $\mathrm{i}$ & ヒ & $3,554,252$ & 11,507 \\
\hline 28 & $\mathrm{CV}$ & $\mathrm{hu}$ & $\mathrm{h}$ & $\mathrm{u}$ & 7 & $3,067,681$ & 11,707 \\
\hline 29 & $\mathrm{CV}$ & he & $\mathrm{h}$ & $\mathrm{e}$ & ヘ & $1,254,559$ & 2,633 \\
\hline 30 & $\mathrm{CV}$ & ho & $\mathrm{h}$ & o & ホ & $4,064,902$ & 8,336 \\
\hline \multicolumn{8}{|c|}{ /b/ and /g/ (Voiced, Stop) } \\
\hline 31 & $\mathrm{CV}$ & ba & $\mathrm{b}$ & a & バ & $2,749,654$ & 10,011 \\
\hline 32 & $\mathrm{CV}$ & bi & $\mathrm{b}$ & $\mathrm{i}$ & ビ & $1,177,824$ & 5,569 \\
\hline 33 & $\mathrm{CV}$ & $\mathrm{bu}$ & $\mathrm{b}$ & $\mathrm{u}$ & ブ & $2,758,994$ & 9,263 \\
\hline 34 & $\mathrm{CV}$ & be & $\mathrm{b}$ & $\mathrm{e}$ & ベ & $1,591,698$ & 3,769 \\
\hline 35 & $\mathrm{CV}$ & bo & $\mathrm{b}$ & o & ボ & $1,104,998$ & 5,317 \\
\hline 36 & $\mathrm{CV}$ & da & $\mathrm{d}$ & $\mathrm{a}$ & ダ & $9,953,427$ & 17,622 \\
\hline 37 & $\mathrm{CV}$ & $\mathrm{de}$ & $\mathrm{d}$ & $\mathrm{e}$ & デ & $7,744,822$ & 5,965 \\
\hline 38 & $\mathrm{CV}$ & do & d & o & ド & $5,306,817$ & 12,158 \\
\hline 39 & $\mathrm{CV}$ & ga & $\mathrm{g}$ & $\mathrm{a}$ & ガ & $11,996,376$ & 17,737 \\
\hline 40 & $\mathrm{CV}$ & $\mathrm{gi}$ & g & $\mathrm{i}$ & ギ & $2,009,223$ & 6,249 \\
\hline 41 & $\mathrm{CV}$ & $\mathrm{gu}$ & $\mathrm{g}$ & $\mathrm{u}$ & グ & $1,210,586$ & 8,951 \\
\hline 42 & $\mathrm{CV}$ & ge & $\mathrm{g}$ & $\mathrm{e}$ & ゲ & $2,328,945$ & 6,422 \\
\hline 43 & $\mathrm{CV}$ & go & $\mathrm{g}$ & o & $\exists$ & $2,549,499$ & 7,088 \\
\hline \multicolumn{8}{|c|}{ /z/ (Voiced, Fricative) } \\
\hline 44 & $\mathrm{CV}$ & $\mathrm{za}$ & $\mathrm{z}$ & $\mathrm{a}$ & ザ & $1,384,993$ & 5,736 \\
\hline 45 & $\mathrm{CV}$ & $\mathrm{zi}$ & $\mathrm{z}$ & $\mathrm{i}$ & ジ & $6,550,231$ & 15,529 \\
\hline 46 & $\mathrm{CV}$ & $\mathrm{zu}$ & $\mathrm{z}$ & $\mathrm{u}$ & ズ & $1,644,763$ & 8,670 \\
\hline 47 & $\mathrm{CV}$ & ze & $\mathrm{z}$ & $\mathrm{e}$ & ゼ & $1,646,454$ & 3,024 \\
\hline 48 & $\mathrm{CV}$ & zo & $\mathrm{z}$ & o & ゾ & 936,779 & 3,125 \\
\hline \multicolumn{8}{|c|}{$/ \mathrm{m} /$ and $/ \mathrm{n} /($ Voiced, Nasal) } \\
\hline 49 & $\mathrm{CV}$ & $\mathrm{ma}$ & $\mathrm{m}$ & $\mathrm{a}$ & $\checkmark$ & $6,289,027$ & 28,364 \\
\hline 50 & $\mathrm{CV}$ & $\mathrm{mi}$ & $\mathrm{m}$ & $\mathrm{i}$ & $\Sigma$ & $3,972,466$ & 21,459 \\
\hline 51 & $\mathrm{CV}$ & $\mathrm{mu}$ & $\mathrm{m}$ & u & 公 & $2,577,386$ & 8,694 \\
\hline 52 & $\mathrm{CV}$ & me & $\mathrm{m}$ & $\mathrm{e}$ & $x$ & $4,118,162$ & 9,174 \\
\hline 53 & $\mathrm{CV}$ & mo & $\mathrm{m}$ & o & $\hat{乇}$ & $6,791,877$ & 12,180 \\
\hline 54 & $\mathrm{CV}$ & na & $\mathrm{n}$ & $\mathrm{a}$ & ナ & $10,498,607$ & 18,207 \\
\hline 55 & $\mathrm{CV}$ & ni & $\mathrm{n}$ & $\mathrm{i}$ & $=$ & $14,757,618$ & 10,038 \\
\hline 56 & $\mathrm{CV}$ & nu & $\mathrm{n}$ & $\mathrm{u}$ & $\bar{x}$ & 411,356 & 2,034 \\
\hline
\end{tabular}


APPENDIX A (Continued)

\begin{tabular}{|c|c|c|c|c|c|c|c|}
\hline & $\begin{array}{c}\text { Phonemic } \\
\text { Combination }\end{array}$ & Mora & Cons/Semi & Vowel & Katakana & Token Frequency & Type Frequency \\
\hline 57 & $\mathrm{CV}$ & ne & $\mathrm{n}$ & $\mathrm{e}$ & ネ & $2,771,906$ & 6,260 \\
\hline 58 & $\mathrm{CV}$ & no & $\mathrm{n}$ & o & ノ & $19,326,674$ & 14,413 \\
\hline \multicolumn{8}{|c|}{ /r/ (Voiced, Liquid) } \\
\hline 59 & $\mathrm{CV}$ & $\mathrm{ra}$ & $\mathrm{r}$ & $\mathrm{a}$ & ラ & $6,947,107$ & 20,442 \\
\hline 60 & $\mathrm{CV}$ & ri & $\mathrm{r}$ & $\mathrm{i}$ & リ & $6,116,529$ & 25,431 \\
\hline 61 & $\mathrm{CV}$ & $\mathrm{ru}$ & $\mathrm{r}$ & $\mathrm{u}$ & ル & $28,899,891$ & 23,656 \\
\hline 62 & $\mathrm{CV}$ & re & $\mathrm{r}$ & $\mathrm{e}$ & レ & $5,777,889$ & 9,566 \\
\hline 63 & $\mathrm{CV}$ & ro & $\mathrm{r}$ & o & 口 & $2,927,552$ & 13,925 \\
\hline \multicolumn{8}{|c|}{ /w/ and /j/ (Voiced, Semivowel) } \\
\hline 64 & SV & ja & $\mathrm{j}$ & a & p & $3,432,278$ & 13,622 \\
\hline 65 & SV & ju & $\mathrm{j}$ & $\mathrm{u}$ & ב & $1,620,066$ & 10,491 \\
\hline 66 & SV & jo & $\mathrm{j}$ & o & $\exists$ & $4,484,240$ & 5,464 \\
\hline 67 & SV & wa & $\mathrm{w}$ & a & ワ & $3,777,201$ & 13,922 \\
\hline \multicolumn{8}{|c|}{$/ \mathrm{pj} /, / \mathrm{tj} /$, and $/ \mathrm{kj} /$ (Voiceless, Stop) } \\
\hline 68 & $\mathrm{CSV}$ & pja & $\mathrm{pj}$ & $\mathrm{a}$ & ピヤ & 95 & 9 \\
\hline 69 & CSV & pju & $\mathrm{pj}$ & $\mathrm{u}$ & ピュ & 29,907 & 147 \\
\hline 70 & CSV & pjo & $\mathrm{pj}$ & o & ピヨ & 125,380 & 82 \\
\hline 71 & CSV & tja & $\mathrm{tj}$ & $\mathrm{a}$ & チャ & 199,251 & 1,216 \\
\hline 72 & CSV & tju & $\mathrm{tj}$ & $\mathrm{u}$ & チュ & 995,900 & 1,898 \\
\hline 73 & CSV & tjo & $\mathrm{tj}$ & o & チョ & $2,206,487$ & 9,007 \\
\hline 74 & $\mathrm{CSV}$ & $\mathrm{kja}$ & $\mathrm{kj}$ & $\mathrm{a}$ & キャ & 166,750 & 551 \\
\hline 75 & CSV & kju & $\mathrm{kj}$ & $\mathrm{u}$ & キュ & 929,206 & 1,814 \\
\hline 76 & CSV & kjo & $\mathrm{kj}$ & o & キョ & $2,721,853$ & 4,139 \\
\hline \multicolumn{8}{|c|}{$/ \mathrm{sj} /$ and $/ \mathrm{hj} /$ (Voiceless, Fricative) } \\
\hline 77 & CSV & sja & $\mathrm{sj}$ & a & シャ & $2,138,138$ & 3,208 \\
\hline 78 & CSV & sju & $\mathrm{sj}$ & $\mathrm{u}$ & シュ & $2,858,438$ & 5,175 \\
\hline 79 & CSV & sjo & sj & o & ショ & $3,740,881$ & 8,688 \\
\hline 80 & CSV & hja & hj & a & ヒヤ & 53,284 & 170 \\
\hline 81 & CSV & hju & hj & $\mathrm{u}$ & ヒュ & 3,304 & 69 \\
\hline 82 & CSV & hjo & hj & o & ヒョ & 577,939 & 700 \\
\hline \multicolumn{8}{|c|}{ /bj/ and /gj/ (Voiced, Stop) } \\
\hline 83 & $\mathrm{CSV}$ & bja & bj & a & ビャ & 511 & 45 \\
\hline 84 & CSV & bju & $\mathrm{bj}$ & $\mathrm{u}$ & ビュ & 16,016 & 83 \\
\hline 85 & CSV & bjo & $\mathrm{bj}$ & o & ビョ & 162,751 & 504 \\
\hline 86 & CSV & gja & gj & $\mathrm{a}$ & ギャ & 59,424 & 207 \\
\hline 87 & CSV & gju & gj & $\mathrm{u}$ & ギュ & 15,343 & 117 \\
\hline 88 & CSV & gjo & $\mathrm{gj}$ & o & ギョ & 937,044 & 2,084 \\
\hline \multicolumn{8}{|c|}{ /zj/ (Voiced, Fricative) } \\
\hline 89 & CSV & zja & $\mathrm{zj}$ & $\mathrm{a}$ & ジャ & 188,263 & 1,166 \\
\hline 90 & CSV & zju & $\mathrm{zj}$ & $\mathrm{u}$ & ジュ & $1,482,387$ & 3,623 \\
\hline 91 & CSV & zjo & $z j$ & o & ジョ & $2,041,928$ & 4,929 \\
\hline \multicolumn{8}{|c|}{$/ \mathrm{mj} /$ and /nj/ (Voiced, Nasal) } \\
\hline 92 & $\mathrm{CSV}$ & mja & $\mathrm{mj}$ & a & ミャ & 14,646 & 113 \\
\hline 93 & CSV & mju & $\mathrm{mj}$ & $\mathrm{u}$ & ミュ & 15,494 & 201 \\
\hline 94 & CSV & mjo & $\mathrm{mj}$ & o & ミョ & 33,782 & 400 \\
\hline 95 & CSV & nja & nj & $\mathrm{a}$ & ニャ & 3,087 & 69 \\
\hline 96 & CSV & nju & $\mathrm{nj}$ & $\mathrm{u}$ & ニュ & 446,886 & 738 \\
\hline 97 & CSV & njo & nj & o & ニョ & 10,406 & 175 \\
\hline \multicolumn{8}{|c|}{ /rj/ (Voiced, Liquid) } \\
\hline 98 & $\mathrm{CSV}$ & rja & $\mathrm{rj}$ & $\mathrm{a}$ & リヤ & 50,769 & 183 \\
\hline 99 & CSV & rju & $\mathrm{rj}$ & $\mathrm{u}$ & リュ & 214,108 & 1,122 \\
\hline 100 & CSV & rjo & $\mathrm{rj}$ & o & リョ & $1,541,224$ & 2,442 \\
\hline \multicolumn{8}{|c|}{ /N/ (Voiced, Nasal) } \\
\hline 101 & $\mathrm{~N}$ & $\mathrm{~N}$ & - & - & ン & $35,719,268$ & 81,463 \\
\hline \multicolumn{8}{|c|}{ /R/ (Long Vowel Including Two Same Vowels Simply Continued) } \\
\hline 102 & $\mathrm{R}$ & $\mathrm{R}$ & - & - & - & $3,607,169$ & 23,598 \\
\hline \multicolumn{8}{|c|}{ /Q/ (Geminate) } \\
\hline 103 & Q & $\mathrm{Q}$ & - & - & ツ & $7,858,931$ & 14,435 \\
\hline
\end{tabular}


APPENDIX B

Frequency Counts of 33 Additional Morae (or Kana) Used for Describing Alphabetic Loanwords

\begin{tabular}{|c|c|c|c|c|c|c|c|}
\hline & $\begin{array}{l}\text { Phonemic } \\
\text { Combination }\end{array}$ & Mora & Cons/Semi & Vowel & Katakana & Token Frequency & Type Frequency \\
\hline 102 & CSV & sje & sj & e & シェ & 14,924 & 149 \\
\hline 103 & CSV & cje & $\mathrm{cj}$ & $\mathrm{e}$ & チェ & 37,633 & 269 \\
\hline 104 & $\mathrm{CV}$ & $\mathrm{ca}$ & $\mathrm{c}$ & $\mathrm{a}$ & ツァ & 2,465 & 43 \\
\hline 105 & $\mathrm{CV}$ & ce & $\mathrm{c}$ & $\mathrm{e}$ & ツェ & 4,802 & 38 \\
\hline 106 & $\mathrm{CV}$ & co & $\mathrm{c}$ & o & ツオ & 675 & 14 \\
\hline 107 & $\mathrm{CV}$ & ti & $\mathrm{t}$ & $\mathrm{i}$ & ティ & 66,313 & 1,205 \\
\hline 108 & $\mathrm{CV}$ & $\mathrm{fa}$ & $\mathrm{f}$ & $\mathrm{a}$ & ファ & 60,484 & 681 \\
\hline 109 & $\mathrm{CV}$ & fi & $\mathrm{f}$ & $\mathrm{i}$ & フィ & 50,615 & 474 \\
\hline 110 & $\mathrm{CV}$ & $\mathrm{fe}$ & $\mathrm{f}$ & $\mathrm{e}$ & フェ & 16,129 & 346 \\
\hline 111 & $\mathrm{CV}$ & fo & $\mathrm{f}$ & o & フォ & 31,399 & 408 \\
\hline 112 & CSV & zje & $\mathrm{zj}$ & $\mathrm{e}$ & ジェ & 30,738 & 255 \\
\hline 113 & $\mathrm{CV}$ & $\mathrm{di}$ & d & $\mathrm{i}$ & ディ & 65,994 & 947 \\
\hline 114 & CSV & dju & $\mathrm{dj}$ & $\mathrm{u}$ & デュ & 8,344 & 65 \\
\hline 115 & SV & $\mathrm{je}$ & $\mathrm{j}$ & $\mathrm{e}$ & イェ & 20 & 7 \\
\hline 116 & SV & wi & w & $\mathrm{i}$ & ウィ & 12,605 & 170 \\
\hline 117 & SV & we & $\mathrm{w}$ & $\mathrm{e}$ & ウェ & 25,909 & 226 \\
\hline 118 & SV & wo & $\mathrm{w}$ & o & ウォ & 7,747 & 109 \\
\hline 119 & $\mathrm{CSV}$ & kwa & $\mathrm{kw}$ & $\mathrm{a}$ & クァ & 21 & 2 \\
\hline 120 & $\mathrm{CSV}$ & kwi & $\mathrm{kw}$ & $\mathrm{i}$ & クィ & 20 & 6 \\
\hline 121 & $\mathrm{CSV}$ & kwe & $\mathrm{kw}$ & $\mathrm{e}$ & クェ & 2 & 1 \\
\hline 122 & CSV & kwo & $\mathrm{kw}$ & o & クォ & 85 & 10 \\
\hline 123 & $\mathrm{CV}$ & $\mathrm{ci}$ & $\mathrm{c}$ & $\mathrm{i}$ & ツィ & 13,067 & 15 \\
\hline 124 & $\mathrm{CV}$ & tu & $\mathrm{t}$ & $\mathrm{u}$ & トゥ & 1,854 & 78 \\
\hline 125 & CSV & gwa & gw & $\mathrm{a}$ & グァ & 25 & 5 \\
\hline 126 & $\mathrm{CV}$ & $\mathrm{du}$ & d & $\mathrm{u}$ & ドゥ & 1,542 & 55 \\
\hline 127 & CSV & vwa & $\mathrm{vw}$ & $\mathrm{a}$ & ヴァ & 641 & 80 \\
\hline 128 & CSV & vwi & vw & $\mathrm{i}$ & ヴィ & 733 & 81 \\
\hline 129 & $\mathrm{CV}$ & $\mathrm{vu}$ & $\mathrm{v}$ & $\mathrm{u}$ & ヴ & 283 & 29 \\
\hline 130 & CSV & vwe & vw & $\mathrm{e}$ & ヴェ & 311 & 38 \\
\hline 131 & CSV & vwo & $\mathrm{vw}$ & o & ヴオ & 66 & 15 \\
\hline 132 & CSV & tju & $\mathrm{tj}$ & $\mathrm{u}$ & テュ & 72 & 8 \\
\hline 133 & CSV & fju & $\mathrm{fj}$ & $\mathrm{u}$ & フュ & 206 & 7 \\
\hline 134 & CSV & vju & $\mathrm{vj}$ & $\mathrm{u}$ & ヴュ & 34 & 4 \\
\hline
\end{tabular}

Note-The 33 additional kana are listed on the basis of the Cabinet Announcement of the Government of Japan (1991). The frequencies of the 33 kana were counted using words described in katakana. The phonemic expressions of these kana were basically adapted from Matsuzaki (1993), with a few exceptions, such as /v/ for ヴァ,ヴィ,ヴ,ヴェ, and ヴォ.

(Manuscript received July 23, 2003;

revision accepted for publication June 4, 2004.) 